\begin{tabular}{llc}
\hline Mezhep Araştırmaları Dergisi & 13, sy. 1 & (Bahar 2020): 3-37 \\
\hline Journal of Islamic Sects Research & 13, no. 1 & (Spring 2020): 3-37 \\
\hline Hakemli Araştırma Makalesi | Peer-reviewed Research Article
\end{tabular}

Hakemli Araştırma Makalesi | Peer-reviewed Research Article

\title{
Musâhiblik Konusunun Din Kültürü Ve Ahlak Bilgisi Müfredatında Yer Alış Şekli Üzerine Bir Değerlendirme
}

An Evaluation on The Handling of the Musahiblik Subject in The Curriculum of Religious Culture and Ethics Course

\section{Cenksu ÜÇER ${ }^{1}$}

\section{Öz}

Bu çalışmada, Musâhiblik konusunun Din Kültürü ve Ahlak Bilgisi dersi (DKAB) müfredatında yer alış şekli isslenmektedir. Burada ele alınan Musâhiblik, Alevî nitelemeli geleneğe mensup ocak ve grupların bazısında yer almaktadır. Ancak söz konusu ocak ve gruplar arasinda da farklı anlamlandirmalar ve uygulamalarla varlığını sürdürmektedir. Yaygın şekliyle "evli iki ailenin dünya ve ahiret kardeşliğini" ifade eden Musâhiblik, bir nevi sosyal dayanışma içerikli geleneksel bir kurumsal yapıyı ifade etmektedir. Dünyada ve ülkemizde görülen modernleşme ve şehirleşme vb. birtakım etkilere bağlı olarak Musâhiblik gibi kurumlar, günümüzde işlevini yitirmeye başlamış ve unutulmaya yüz tutmuştur. Dünyada ve ülkemizde yaşanan gelişmelere bağlı olarak 2005 yılından itibaren Alevî gelenek açısından önemli görülen birtakım konular DKAB dersinin müfredat1 içerisinde yer almaya başlamıştır. $\mathrm{Bu}$ konulardan biri de Musâhibliktir. Gelinen noktada Musâhibliğin İlköğretimde 7, Ortaöğretimde ise 12. siniflarda işlendiği görülmektedir. Müfredatta Musâhibliğin Alevî nitelemeli bütün ocak ve gruplarda varmış gibi bir algıya neden olacak tarzda işlenmesi dikkat çek-

\section{Abstract}

This article deals with the subject of Musahiblik how it is handled in the curriculum of Religious Culture and Ethics Course. The institution of Musahiblik mentioned here is found in some "ocak"s (lodge) and groups named Alevi. However, it continues to exist with different interpretations and practices among these "ocak"s and groups. The Musahiblik that commonly indicates the brotherhood of the two married families in the worldly life and the Hereafter, expresses a traditional institutional structure involving social solidarity. Today, as a result of modernization and urbanization etc. seen in the world and our country, the institutions like the Musahiblik started to lose its function and to be forgetten. Depending on developments in the world and our country, some issues deemed important for the Alevi tradition started to take place in the curriculum of Religious Culture and Ethics Course since 2005. One of these issues is the Musahiblik. It is observed that the subject of Musahiblik is processed in 7 th grades in the primary education and 12th grades in the secondery education today. It stands out in

1 Prof. Dr., Ankara Yıldırım Beyazıt Üniversitesi İslami İlimler Fakültesi

Öğretim Üyesi, e-posta: cenksu.ucer@ybu,edu.tr; hcenksuucer@hotmail.com, ORCID ID: orcid.org/0000-0001-9874-2990.

\begin{tabular}{ccc}
\hline $\begin{array}{c}\text { Başvuru|Submission } \\
\text { 08.06.2020 }\end{array}$ & $\begin{array}{c}\text { Kabul| Accept } \\
23.06 .2020\end{array}$ & $\begin{array}{c}\text { Yayın | Publish } \\
30.06 .2020\end{array}$ \\
\hline DOI: $\quad 10.18403$ /emakalat.749312 &
\end{tabular}


mektedir. Ayrıca Musâhibliğin tek isimle ve bütün gruplarda aynı anlamlandırma ve uygulamalarla var olduğu şeklinde sunulduğu da görülmektedir.

Anahtar Kelimeler: Alevî Gelenek, Musâhiblik, Din Kültürü ve Ahlak Bilgisi Müfredatı, Ocak, Gruplar. the curriculum that the musahiblik is processed in a manner that causes a perception as if it existed in all the Alevi "ocak"s and groups. It is also seen that the Musahiblik is presented as a single name and as if it existed with the same interpretations and practices among all these "ocak"s and groups.

Key Words: Alevî Tradition, The Musahiblik, The Curriculum of Religious Culture and Ethics Course, Ocak's, Groups.

\section{Giriș}

Bu çalışmada, Musâhiblik² konusunun Din Kültürü ve Ahlak Bilgisi (DKAB) dersi müfredatında yer alış şekli işlenmektedir. Burada yer verilen Musâhiblik, Alevî nitelemeli geleneğe mensup ocak ve grupların bazısında yer almaktadır. Ancak söz konusu ocak ve gruplar arasinda da farklı anlamlandirmalar ve uygulamalarla varlığını sürdürmektedir. Yaygın şekliyle "evli iki ailenin dünya ve ahiret kardeşliğini" ifade eden Musâhiblik, -geçmişe göre zayıflasa da- bir nevi sosyal dayanıssma içerikli geleneksel bir kurumsal yapiyı ifade etmektedir. ${ }^{3}$

Musâhiblik konusunun DKAB müfredatında yer alış șeklinin sağlıklı bir biçimde değerlendirilmesi için öncelikle söz konusu bu kurumsal yapının ortaya konulması gerektiği açıktır. Ayrıca

2 Kelimenin gerek MEB içeriklerinde gerek kitaplarda Musahiplik şeklinde; Makalemizin Kaynakçasına göz atıldığında görüleceği üzere yayımlanan eser ve makalelerde ise farklı şekillerde yazılabildiği anlaşılmaktadır. Musâhiblik kavramının hem DKAB Öğretim Programında hem ders kitaplarında "Musahiplik" şeklinde kullanılması "Millî Eğitim Bakanlığı Ders Kitapları ve Eğitim Araçları Yönetmeliği”nin, öğretim programlarında ve ders kitaplarında "güncel Türkçe" kullanma, TDK’nın yazım ve imlasına "uyma" gibi ölçütleri nedeniyle olduğu açıktır. E-makâlât Dergimizde de bu noktada kayıtlar olsa da, özellikle yaygın olarak kullanılmayan bu tarz kelime, kavram ve tamlamalarda zaman zaman akademik çalıșmalarda da bir takım sınırlandırmalar ya da ifadede güçlükler yaşandığı malumdur. Bu çalışmada, kavramın doğru telaffuzu açısından Musâhiblik yazımı tercih edilmiştir.

3 Fevzi Rençber, "Niyazi Arslan Dede ile Adıyaman'da Alevilik Üzerine", The Journal of Academic Social Science Studies 5/3 (2013): 550; Cenksu Üçer, Alevîlikte Musâhiblik (Ankara: Araștırma Yayınları, 2015), 232; Mehmet Ersal, Alevilik Kavramlar ve Ocak Sistemi -Çubuk Havzası Örneği- (Ankara: Türk Kültürü ve Hacı Bektaş Veli Araştırma Merkezi Yayınları, 2016), 379. 
Musâhiblik konusunda Alevî nitelemeli ocak ve gruplar arasında görülen anlamlandırma ve uygulama farklılıklarının anlaşılması adına da Alevî gelenek içerisinde görülen ocak ve grupların farklilıklarına da işaret edilmesi bir zorunluluktur.

Bu itibarla çalışmamızda öncelikle Musâhiblik konusu ele alınmış, farklı anlayıș ve uygulamaların ortaya konulması adına Alevî gelenek içerisinde görülen ocak ve grupların farklılıklarına işaret edilmiş, bu çerçeve çizildikten sonra konunun DKAB müfredatında ele alınış şekli işlenerek değerlendirmeler paylaşılmıştır.

Burada daha önceki çalışmalarımızda da üzerinde önemle durulan bir hususa tekrar yer vermekte fayda mülahaza edilmektedir. Günümüzde daha çok Alevî nitelemesi kullanılan toplulukların geleneksel olarak ocak sistemine dayanmas1, ocakların farklı silsilelere sahip olması, yine farklı tasavvufî geleneklere mensup olması ve şehirleşmeyle birlikte farklı Alevîlik anlayışları etrafında bir örgütlenme yaşanması gerçeği, çalışma(ları)mızda "Alevî nitelemeli gelenek ya da ocaklar ve gruplar" şeklinde bir ifade kullanmayı gerekli kılmaktadır. Burada "Alevî gelenek" ifadesi ile ocak ve grupların geleneksel olarak sahip oldukları tasavvuf hayatı bağlamında şekillenen temel anlayış ve zihniyeti; "ocaklar" ile geleneksel yapıyı; "gruplar" ile ise şehirleşmeyle ortaya çıkan farklı anlayışlar çerçevesinde görülen örgütlenme bağlamındaki mensubiyeti ifade etmeye çalıştığımız dile getirilmelidir.

\section{Musâhiblik}

\section{1. İsimlendirme}

Musâhib kelimesi4 "sohbetleşen, sohbet arkadaş1, sohbet ehli kimse, arkadaş, dost" anlamlarına gelir. ${ }^{5}$ Musâhib kelimesinin terim olarak biri Osmanlı saray teşkilatında diğeri Alevî nitelemeli gelenekte olmak üzere iki alanda kullanıldığı görülmektedir.

Osmanlı saray teşkilatında musâhib bir unvandır. Buna göre musâhib kelimesi, "Osmanlı saray teşkilatında saraydaki görevliler içinde vezir ve beylerbeylerinden padişaha danışmanlık yapan,

4 Arapça sohbet (s-h-b) kökünün 'mufâale' kalıbında 'karşılıklı sohbet etmek' anlamındaki sâhabe (mastarı musâhabe) fiilinden ism-i fâil olarak türemiştir. Hasan Saîd Keremî, el-Hâdî ilâ Lügati'l-'Arab (Beyrut: Dâr-u Lübnân, 1992), 4: 9-10.

5 Abdülbaki Gölpınarlı, Tasavvuf'tan Dilimize Geçen Deyimler ve Atasözleri (İstanbul: İnkilap ve Aka Kitabevleri, 1977), 224. 
kişiliği ve bilgisiyle temayüz ederek ona arkadaşlıkta bulunanlar için kullanılmıştır." 6

Musâhib kelimesi Alevî nitelemeli gelenekte, geleneğe mensup kimi ocak ve gruplarda var olan ve yaygın olarak iki ailenin kardeşliğini ifade eden, ${ }^{7}$ dînî olarak tarikat hayatı kalıplarında şekillendirilen sosyal bir kurumun adıdır. ${ }^{8}$

Alevî geleneğe mensup kimi ocaklarda Musâhiblik, "Yaşları reşit (kişilik kazanmış) iki erkek müslümanın, birbirleriyle anlaşarak bir dînî temsilci önünde yaptıkları yeminli kardeşlik bağı kurmalarını"9 veya "daha önce ikrâr vermiş olan ve kan bağı da taşımayan evli iki kişinin eşleri ile birlikte, dedenin ve cem topluluğunun önünde, Hakk'a yürüyünceye kadar kardeş kalacaklarına, birbirini kollayıp koruyacaklarına, birlik ve beraberlik içinde yaşayacaklarına dair söz vermeleri şeklinde gerçekleştirilen bir törenle kurulan manevî kardeşliği" ifade etmektedir. ${ }^{10}$

Musâhiblik bölgeden bölgeye, ocaktan ocağa bilazerlik, can kardeşliği/yoldaşlığı, din kardeşliği, hısımlık, sağdıçlık, tarikat kardeşliği vb. farklı şekillerde isimlendirilmiştir. Bununla birlikte Musâhibliğe, yolun gereği olduğu ve bu dünya hayatında insanlar arasında dayanışmayı hedeflediği için yol kardeşliği, bu beraberliğin ölünceye kadar sürmesi gerekliliği ve musâhibe karşı kişinin yaptıklarından dolayı ahirette sorumlu tutulacağı anlayışına bağlı olarak ahiret/ahret kardeşliği gibi isimler de verildiği görülmektedir. ${ }^{11}$ Tahtacılar Musâhibliğe ahiret kardeşliği ya da yol

6 Mehmet Zeki Pakalın, Osmanlı Tarih Deyimleri ve Terimleri Sözlüğü (I-III) (İstanbul: MEB Yayınlar1, 1993), 2/583; Mehmet İpşirli, "Musâhib", Türkiye Diyanet Vakfı İslâm Ansiklopedisi (İstanbul: TDV Yayınları, 2006), 31: 230.

7 Ahmet Uğurlu, Alevilikde Cem ve Musâhiblik (İstanbul: Ufuk Matbaas1, 1991), 13; Seyit Derviş Tur, Erkânname, Aleviliğin İslâm'da Yeri ve Alevi Erkânlarn (İstanbul: Can Yayınları, 2002), 421.

8 Cenksu Üçer, "Musâhiblik Kurumu Üzerinden Alevî Ocaklar ve Gruplar Hakkında Bazı Değerlendirmeler", Türk Kültürü ve Hacı Bektaş Veli Araştırma Dergisi 93 (2020): 13.

9 Haydar Kaya, Musâhiblik (İstanbul: Engin Yayınc1lık, 1989), 11.

10 Harun Yıldız, "Alevî/Bektaşî Geleneğinde Musahiplik", Uluslarası Bektaşilik ve Alevilik Sempozyumu -I- Bildiriler-Müzakereler (SDÜ Üniversitesi Yayınları: Isparta, 2005), 123-132; Rıza Yıldırım, Geleneksel Alevilik İnanç, İbadetler, Kurumlar, Toplumsal Yapi, Kolektif Bellek (İstanbul: İletişim, 2018), 246-247.

11 Esat Korkmaz, Ansiklopedik Alevilik Bektaşilik Terimleri Sözlüğü (İstanbul: Ant Yayınları, 1994), 253-254; Emrah Özdemir, "Geleneksel Alevilikte Musahiplik ve Musahip Erkânı Samsun İli Havza ve Lâdik İlçeleri Örneği", Hitit Üniversitesi Hact Bektaş Veli Araştırma ve Uygulama Merkezi I. Uluslararası Hacı Bektaş Veli Sempozyumu (Çorum: 2011), 2/736; Berna Ayaz, "Balıkesir Çepni ve Tahtacılarında Musahiplik Geleneğinin Toplum Yaşamındaki İşlevi”, Alevilik Araştırmaları Dergisi 5 (2013): 103; Mehmet 
kardeşliği gibi isimlendirmelerle beraber aynı zamanda içeri kurbanı da demektedir. ${ }^{12}$

\subsection{Kökeni ve Mahiyeti}

Araștırmacılar, Alevî nitelemeli geleneğe mensup kimi ocak ve gruplar arasında geleneksel olarak oldukça önemli dînî ve sosyal fonksiyonlar icra eden Musâhibliğin kökeni hakkında değişik görüşler ileri sürmüştür. Musâhiblik farklı coğrafya ve orijine bağlanmakta ve bu hususta geçmişte Türk kavimleri arasında var olduğu bilinen anda (yeminli dostluk andlaşmast), biste (kardeşlik,ortaklık), alplik, nögerlik (arkadaşlık) gibi adet ve uygulamalara dikkat çekilmektedir. ${ }^{13}$ Bununla birlikte genellikle Musâhiblik kurumu, zamanında Anadolu coğrafyasında çok önemli fonksiyonlar icrâ eden Fütüvvet ve Ahîlik geleneğiyle bağlantılı görülmektedir. ${ }^{14}$ Âdâb ve erkân kitabı olan ve Buyruk olarak isimlendirilen ${ }^{15}$-ki bu eserlerin çoğunun Erdebil Sûfiyân Süreğine/

Ersal, "Alevi İnanç Sistemindeki Ritüelik Özel Terimler: Musahiplik", Turkish Studies 6/1 (2011): 1106-1107; Hüseyin Dedekargınoğlu, "Dede Garkın Ocağı'nda Musahiplik Uygulaması Örneği”, Türk Kültürü ve Hacı Bektaş Veli Araştırma Dergisi 78 (2016): 92; Y1lmaz Irmak - Handan Hamarat, "Bingöl Aleviliğinde Dedelik Musahiplik Düşkünlük ve Cem”, Bingöl Üniversitesi Sosyal Bilimler Enstitüsü Dergisi 8/15 (2018): 218.

12 Ali Selçuk, Tahtacılar (İstanbul: Yeditepe Yayınlar1, 2004), 189.

13 İrene Melikoff, Uyur İdik Uyardılar Alevîlik-Bektaşîlik Araştırmaları, trc. Turan Alptekin (İstanbul: Cem Yayınları, 1994), 90-91. Daha detay değerlendirmeler için bkz. Abdülkadir İnan, "Eski Türklerde ve Folklorda Ant", Dil Tarih Coğrafya Fakültesi Dergisi 6/4 (1948): 279-290; A. Zeki Velidî Togan, Oğuz Destanı Reşideddin Oğuznâmesi, Tercüme ve Tahlili (İstanbul: Ahmet Sait Matbaas1, 1972), 65-67, 106-107; Orhan Şaik Gökyay, Dede Korkut Hikâyeleri (İstanbul: Kültür Bakanlığı Yayınları, 1976), 67; Kaşgarlı, Mahmud, Divanü Lûgati't-Türk, haz. Besim Atalay (Ankara: TDK Yayınları, 1986), 3/ 7172, 4/95; Nejat Birdoğan, Anadolu ve Balkanlar'da Alevi Yerleşmesi Ocaklar-Dedeler-Soyağaçları (İstanbul: Mozaik Yayınları, 1995), 34; Hüseyin Bal, Alevi-Bektaşi Köylerinde Toplumsal Kurumlar (İstanbul: Ant Yayınlar1,1997), 52; Halil İnalcık, "Osmanlı Devletinin Kuruluş Problemi", Doğu Batı 7 (1999): 19; Ayhan Yalçınkaya, Küf Dede Korkut, Said Nursî ve Hz. Ali Üzerine (İstanbul: Alan Yayınlar1, 2003), 172-182; Dilaver Düzgün, "Divanü Lügati't-Türk'te Sosyal Normları Karşılayan Kavramlar", Atatürk Üniversitesi Türkiyat Araştırmaları Enstitüsü Dergisi 35 (2007) 211.

14 Melikoff, Uyur İdik, 91; M. Saffet Sarıkaya, Anadolu Alevîliğinin Tarihî Arka Planı (XI-XIII. Yüzyıl) (İstanbul: Ötüken Yayınları, 2003), 201-202; aynı yazar, "Bektaşî ve Alevî Kültürünün Yazılı Kaynağı Olarak Fütüvvetnameler", Alevilik Araştırmalar Dergisi 4 (2012): 45.

15 Buyruk, haz. Sefer Aytekin (Ankara: Emek Basım-Yayımevi, 1958), 3; Doğan Kaplan, Yazılı Kaynaklarına Göre Alevîlik (Ankara: TDV Yayınları, 2010), 99100; Cenksu Üçer, Anadolu'da Alevî Ocakları ve Grupları (Ankara: Ankara Okulu Yayınları, 2020), 31-32. 
Kızılbaşlı̆ga mensup ocaklara ait olduğu bilinmektedir. ${ }^{16}$ nüshalarda yer alan Musâhiblik erkânına ait metinlerin kaynaklarının daha çok Fütüvvet/Ahî geleneği olduğu yönündeki tespitler ${ }^{17}$ de bu durumu teyit etmektedir.

Buyruk nüshalarının Musâhibliği farklı olaylara dayandırdığı görülmektedir. Bunun geleneğe de yansıdığı anlaşılmaktadır. Buna göre bazı nüshalarda ve gelenek mensuplarınca konu $\mathrm{Hz}$. Peygamber'in Vedâ Hacc1 dönüşü Gadirhum Olayına dayandırılmaktadır. ${ }^{18}$ Kimi zaman konu Hz. Peygamber'in Miraç hadisesine bağlı olarak ele alınsa da ${ }^{19}$, Alevî gelenek bu kurumu daha çok Hz. Peygamber'in Mekke'den Medine'ye hicreti sonrasında Medine'de tesis etmiş olduğu kardeşlik (muâhât) müessesesine; dolayısıyla Hz. Peygamber'in kendisine Hz. Ali'yi kardeş seçmesi olayına dayandırmaktadır. ${ }^{20}$

Geleneksel Alevîlikteki temel kabule göre $\mathrm{Hz}$. Peygamber kardeşlik müessesesi olan Musâhibliği Kur'an'in emri doğrultusunda kurmuştur. Nitekim bu konuda genellikle Nisâ suresinin 33., Enfâl suresinin 72-75., Tevbe suresinin 71 ve 100., Sebe' suresinin 46., Fetih suresinin 10. ve Hadîd suresinin 10. ayetleri gibi mü'minlerin dostluğunu, velâyetini ve kardeşliğini konu edinen ayetler delil olarak kullanılmaktadır. Söz gelimi Musâhiblik kurumunun tesisi Medine'de kurulan muâhâtı ifade eden Enfâl suresinin 72 . ayetine ${ }^{21}$ dayandırılmaktadır. Kurumun işleyiş şeklinin ise Nisâ suresinin 33. ayetine, ${ }^{22}$ özellikle de ayet-i

16 Üçer, Alevî Ocakları ve Gruplar, 34-35.

17 Sarıaya, Tarihî Arka Plan, 201-202.

18 M. Saffet Sarıkaya, "Bektaşî ve Alevî Kültürünün Yazılı Kaynaklarından Fütüvvetnameler”, Anadolu'da Aleviliğinin Dünü ve Bugünü, edit. Halil İbrahim Bulut (Sakarya: Sakarya Üniversitesi Yayınları, 2010), 375.

19 İmam Cafer-i Sadık Buyruğu, haz. Adil Ali Atalay (İstanbul: Can Yayınları, 1998), 23-25; Buyruk, haz. Fuat Bozkurt (İstanbul: 1982), 12-16; Dedekargınoğlu, "Musahiplik Uygulaması Örneği”, 96.

20 H. İbrahim Bulut, "Türkmen Geleneğinde Sosyal Dayanışma ve Kardeşlik Kurumu Olarak Musahiplik", Kutlu Doğum Haftası "Hz. Peygamber Kardeşlik Ahlakı ve Kardeşlik Hukuku" Sempozyumu (Ankara: 2013), 455-459; Dedekargınoğlu, "Musahiplik Uygulaması Örneği”, 96; Yıldırım, Geleneksel Alevilik, 248; Rifat Türkel, "Sofça Örnekleminde Kalburcu Şeyhi Pîr Ahmed Efendi ve Alevîlik Anlayış1", Insan ve Toplum Dergisi 6/ 1 (2016): 47-62.

21 Ayetin meali şu şekildedir: "Iman edip hicret eden ve Allah yolunda mallariyla, canlariyla cihad edenler ve (muhacirleri) barndırip (onlara) yardım edenler var ya, işte onlar birbirlerinin velileridir." Kur'ân-ı Kerìm Meali, çev. Halil Altuntaş - Muzaffer S,ahin (Ankara: Diyanet İşleri Başkanlığ Yayınları, 2009), el-Enfal 8/72.

22 Ayetin meali şu şekildedir: "(Erkek ve kadından) her biri için ana-babanın ve akrabanın bıraktıklarından (pay alan) varisler kıldık. Yeminlerinizin bağladığ 
kerimenin "Yeminlerinizin bağladiğı (ahitleştiğiniz) kimselere de kendi hisselerini verin." kısmıla açıklandığı görülmektedir. ${ }^{23}$

Alevî nitelemeli kimi ocak ve gruplar arasında toplumsal yardımlaşma ve dayanışmayı tesis eden bir kurum olarak varlığını sürdüren Musâhibliğin, Anadolu'da değissik yörelerde ve kesimler arasında Yaren, Barana, Delikanlı Teşkilatı, Gezek, Muhabbet, Oda Teşkilat1, Sohbet, Sira, Perde, Arfana vb. farklı isimler ve değişik işleyişlerle sürdürülmüş olan ve toplumsal yardımlaşma ve dayanışma fonksiyonu icrâ eden pek çok oluşumla aynı kaynaklardan beslenmesi dikkate değerdir. ${ }^{24}$ Dolayısıla Musâhibliğin, kökeni mutlaka daha eskilere dayansa da, Anadolu'da toplumsal yardımlaşma ve dayanıssma fonksiyonu icrâ eden pek çok oluşumda görülen anlayış ve ilkelerin, boy, soy, aşiret sistemine dayalı ve ilk İslâmlaşma döneminde daha çok göçebe ya da yarı göçebe, son zamanlara kadar kırsal kesim şartlarında şekillenen sosyal bir yapı ile bu iki temel sosyal özelliğe göre uyarlanmıs bir tasavvuf ve tarikat hayatı kalıplarında şekillen Alevî zümrelerin sosyal ve dînî hayatına göre hal almış bir şekli olduğu anlașilmaktadır. ${ }^{25}$

\subsection{Musâhiblik Hukuku}

Günümüzde kendileri daha çok Alevî ismiyle anılan ocak ve gruplar arasında Musâhibliğin farklı şekillerde anlamlandırıldığı görülmektedir. Buna göre Musâhiblik Babağân Bektâşîlerce nasip alma (tarikata girişle birlikte nasip alan diğer kimselerle kardeş ve dost olma) olarak görülmekte, ${ }^{26}$ bazı ocaklarca tarikata giriş (ikrâr) erkânı olarak algılanmakta, diğer bazılarınca ise ikrâr vermiș (tarikata girmiş) olan ailelerden ikisinin ayrıca kardeşlik ahdi yapmaları şeklinde anlaşılmaktadır.

(ahitleştiğiniz) kimselere de kendi hisselerini verin. Şüphesiz Allah her şeye şahittir." en-Nisâ 4/33.

23 Kaya, Musahiblik, 25-46; Mehmet Yaman, Alevîlik İnanç-Edeb-Erkân (İstanbul: Ufuk Reklamcilik ve Matbaacilik, 2001), 242-243.

${ }^{24}$ Neşet Çăgatay, Bir Türk Kurumu Olarak Ahilik (Ankara: AÜİF Yayınları, 1974), 161-174; Tülay Er, Simav İçesi ve Çevresi Yaren Teşkilatı (Ankara: Kültür ve Turizm Bakanlığı Yayınları, 1988), 2-17, 63-64. Nitekim geleneğe ait eserlerde mezhebi ve meşrebi anlayışlar bağlamında daha çok Anadolu'da hakim olan dînî anlayışların görülmesi bu hususun doğal olduğunu göstermektedir. Ömer Faruk Teber, Bektâşî Erkânnâmelerinde Mezhebi Unsurlar (Ankara: Aktif Yayınları, 2008).

25 Üçer, Musâhiblik, 46, 84-85, 93.

26 Ersal, "Ritüelik Özel Terimler: Musahiplik", 1089. 
Musâhiblik denildiğinde yaygın olarak kabul edilenin üçüncüsü olduğu görülmektedir. ${ }^{27}$ Buna göre Alevî geleneğe mensup kimi ocak/gruplarda geleneksel bir kurum olarak Musâhiblik, kan bağ1 taşımayan iki evli kişinin eşleri ile birlikte, Hakk'a yürüyünceye kadar kardeş kalacaklarına, her açıdan birbirini kollayıp koruyacaklarına dair dedenin ve cem topluluğunun önünde söz vermelerini içeren bir tören/erkânla kurulan manevî kardeşliği ifade etmektedir. ${ }^{28}$

\subsubsection{Musâhib Kardeş Olacaklarda Aranan Genel Şartlar}

Manevî bir kardeşliği ifade eden Musâhiblik andlaşması, tarafları ömür boyu sürecek bir tarzda maddî-manevî ağır mükellefiyetler altına aldığından dolayı, musâhib olacak kişiler için bu sorumlulukları hakkıyla yerine getirmelerine yönelik hem kişilik özellikleri hem sosyal çevre ve statüleri açısından bazı şartlar getirildiği görülmektedir. Buna göre, manevî mertebe açısından uygun olan kişi musâhib seçilmeli, sosyal statü açısından akran ve emsâl tercih edilmeli ve aynı yerleşim yerinde yaşayanlar ile aynı dili konuşanlar birbiriyle bu andlaşmayı yapmalıdır. ${ }^{29}$ Ayrıca ocaklar arasında bazı farklı anlayışlar olmakla birlikte Musâhiblik kavline girecek olanlar yirmili yaşlarında olmalıdır. ${ }^{30}$

Geleneksel Alevîlikte, insanın hayatta olduğu sürece mutlaka musâhibli olması şart koşulmuştur. Musâhibliğin kişinin hayatında yalnız bir kere gerçekleşebildiği, ölüm, düşkünlük, ayrılık gibi durumlarda bozulması halinde yenilenmesinin mümkün olmadığı şeklinde görüş ve kayıtlara rastlansa da ${ }^{31}$ Alevî gelenekte Musâhibliğin bulunduğu ocaklarda Musâhibliğe atfedilen öneme bağlı olarak ölüm gibi doğal ayrılıklarda ya da musâhib kardeşlerden birinin erkânı hakkıyla yerine getirmemesi durumunda akdedilen Musâhiblik andlaşmasının iptaline ve yeni

27 Rençber, "Adiyaman'da Alevîlik Üzerine”, 550; Üçer, Musâhiblik, 232; Ersal, Alevilik Kavramlar ve Ocak Sistemi, 379; Yıldırım, Geleneksel Alevîlik, 246.

28 Üçer, "Musâhiblik Kurumu", 14.

29 Buyruk (Bozkurt), 52-53; Cafer Sadık Buyruğu, 58-59, 61; Kaplan, Yazılı Kaynaklarina Göre Alevîlik, 209-210; Bulut, "Musahiplik, 461-463; Dedekargınoğlu, "Musahiplik Uygulaması Örneği", 97-98; Yıldırım, Geleneksel Alevîlik, 253-255.

30 İsmail Kaygusuz, Aleviliğin Toplumsallaştırılmış Tapınç Kurumlarından Musahiblik (İstanbul: Alev Yayınları, 1991), 17; Cafer Sadık Buyruğu, 63; Nizam Bozkurt, Kur'an'da Alevî Erkânı Erkânname 100 Konu- 100 Deyiş- 100 Ayet (Ankara: 2008), 129-130; Kaplan, Yazılı Kaynaklarına Göre Alevîlik, 207; Üçer, Musâhiblik, 111-119.

31 Buyruk (Bozkurt), 52; Pîri Er, Direnen Kültür Anadolu Aleviliği (İstanbul: Detay Yayınlar1, 2006), 120. 
bir Musâhiblik bağının kurulmasına da imkan tanınmıştır. ${ }^{32} \mathrm{Bu}$ ise Alevî geleneğe mensup bir kişinin musâhibsiz kalmamasına yönelik bir uygulama olarak görülmektedir. ${ }^{33}$

Musâhib olan iki evli aile, Musâhiblik ikrârılyla ${ }^{34}$ ilan ettikleri bu kardeşliklerinin getirdiği sorumluluk çerçevesinde, 'herhangi bir ölüm durumunda geride kalanlara bakmak, iflas veya herhangi bir afet ve facia durumunda yardıma koşmak, mallarını paylaşmak, çocuklarını kollamak, duygusal ortaklık ve ortak davranış gösterebilen bir dostluk kurmak, acı ve mutlulukları paylaşmak suretiyle hayat boyunca maddî ve manevî açıdan tam bir dayanışma içinde olacaklarını ve birbirlerinin kusur ve hatalarından kendilerinin de sorumlu olduklarını' beyan etmis sayılırlar. ${ }^{35}$ Bundan dolayı musâhib kardeşler arasında senlik-benlik olmaması, can-baş verme noktasında kusur gösterilmemesi, birbirlerine tam bir teslimiyet ve rıza ile teslim olmaları, birbirlerinden saklı-gizli isslerinin olmaması, birbirlerinin dertleriyle dertlenmeleri, maddî sıkıntılar noktasında birbirlerine destek olmaları, birbirlerinin evlerine teklifsiz gitmeleri, yiyecek-içecek gibi gıda ve diğer eşyalarını serbestçe kullanabilmeleri, birbirlerini davet etmeleri, birbirlerine misafir olmaları ve daima birbirlerini ziyaret etmeleri vb. hususlar hep bir tarikat erkânı olarak hükme bağlanmıştır. ${ }^{36}$ Burada vurgulanması gereken diğer bazı noktalar ise, musâhib kardeşçe herhangi bir kabahat işlenmesi durumunda diğer kardeşin bundan sorumlu olması ve musâhib kardeşlerin kendilerinin birbirlerinin usul ve füruu ile; -farklı ocaklarda değişik uygulamalar olsa da genellikle- çocuklarının da birbirleriyle evlilik yasağının olmasıdır. ${ }^{37}$

32 Kaplan, Yazılı Kaynaklarina Göre Alevîlik, 207, 211.

33 Nitekim Tahtacılarda musâhib, aşina, peşine ve çiğildaş şeklinde dört aşamalı bir Musâhiblik uygulamasının ön görülmesi ve diğer ocaklarda da "müşkül musâhib" ya da yine "aşinalık" olarak adlandırılan bir uygulamanın varlığı Musâhibliğin sürekli işler bir durumda olmasını sağlamaya yöneliktir. Selçuk, Tahtacılar, 200-201; Üçer, Musâhiblik, 125-127.

34 Ön hazırlıklarından erkânın tamamlanmasına kadar bir Musâhiblik erkânı uygulaması örneği için bkz. Üçer, Musâhiblik, 128-174; Ersal, Alevilik Kavramlar ve Ocak Sistemi, 379-449.

35 Kaplan, Yazılı Kaynaklarina Göre Alevîlik, 370; Ali Albayrak, "Alevi-Bektaşi Ritüelleri ve Temel Kurumlarından Hareketle Sosyal Bütünlessme", Sûfí Araştırmalar 7/ 12 (2015): 31-33.

36 Cafer Sadık Buyruğu, 47-49; Tur, Erkânname, 422; Kaplan, Yazılı Kaynaklarina Göre Alevîlik, 210-211; Üçer, Musâhiblik, 119-122.

37 Yasin İpek, "Tahtacilarda Alevi Terminolojisinden Kimi Örnekler", Alevilik, Haz. İsmail Engin, Havva Engin (İstanbul: Kitap Yayınevi, 2004), 45; 


\subsection{Günümüzde Musâhiblik}

Modernleşme ve şehirleşme Alevî gelenek içindeki ocak ve grup mensupları üzerinde de etki göstermiş, söz konusu etki öncelikle Alevîlerin geleneksel bilgi kaynakları ve otorite ile irtibatlarının zayıflamas1, yaşanan gelişmelerin hem epistemolojik kabuller açısından hem de toplumsal örgütlenme ve otorite açısından yeni oluşumlara zemin hazırlaması ile daha belirgin bir hal almıștır. ${ }^{38}$ Nitekim söz konusu etkenler, başta Musâhiblik olmak üzere Dedelik ve Düşkünlük gibi, ilgili geleneksel olgu içerisinde anlam bulan ve şekillenen anlayış ve kurumsal yapıları kökten sarsmış ve geçmişte Alevî geleneğe mensup toplulukların disiplinli yapısını korumada ve toplumsal dayanışma ve yardımlaşmayı sağlamada önemli roller oynamış olan bu kurumlar, günümüzde işlevini yitirmiş ve unutulmaya yüz tutmuştur. ${ }^{39}$

Alevî nitelemeli geleneğe mensup kimi ocak/topluluklara özgü "tasavvurî ya da sanal akrabalık" üzerinden kurulan böyle bir "toplumsal bağ" ve bir tür dayanışma kurumu olan Musâhibliğin de günümüzde ideal anlamıyla yaşatıldığını söylemek oldukça zordur. Yukarıda da işaret edildiği üzere bu geleneksel kurumun ideal anlamiyla hayata geçirilememesinde, köyden kente göçe de neden olan ekonomik ve sosyal değişimlerin etkisi olduğu muhakkaktır. ${ }^{40}$ Ancak Musâhibliği uygulayan ocaklarda bunun köy ve kasabalarda hatta ocak merkezlerinde dahi iç işleyişteki aksaklıklar dolayısıyla yavaş yavaş kaldırılmaya başlandığı görülmektedir. Alan araştırmalarının da ortaya koyduğu gibi, ${ }^{41}$ Musâhiblik köy ve

Kaygusuz, Musahiblik, 18-19; Kaplan, Yazılı Kaynaklarına Göre Alevîlik, 212; Üçer, Musâhiblik, 122-123.

38 Yalçınkaya, Toplumsal Kurumlar, 6-10; H. Nedim Şahhüseyinoğlu, Alevi Örgütlerinin Tarihsel Süreci (Ankara: İtalik Yayınları, 2001), 58-60.

39 Ali Yaman, "Alevîlerde Dedelik ve Dede Ocakları", Geçmişten Günümüze AlevîBektaşî Kültürü, edit. Ahmet Yaşar Ocak (Ankara: Kültür ve Turizm Bakanlığı Yayınları, 2009), 208; Üçer, Musâhiblik, 191-194; Fevzi Rençber, Hakk Muhammed Ali Aşkı, Adıyaman Alevileri (Ankara: Gece Kitaplığı, 2016), 221.

40 Murat Okan, Türkiye'de Alevilik Antropolojik Bir Yaklaşım (Ankara: İmge Kitabevi, 2004), 75; Ahmet Taşğın, Türkmen Aleviler-Diyarbakır Örneği(İstanbul: Ataç Yayınları, 2006), 103-123.

41 Hüseyin Bal, Sosyolojik Açıdan Alevi-Sünni Farklılaşması ve Bütünleşmesi (İstanbul: Ant Yayınları, 1997), 272; Yılmaz Soyyer, Sosyolojik Açıdan Alevî Bektaşî Geleneği (İstanbul: Seyran, 1996), 126; Recep Cengiz, Çamiçi Beldesinde Dini Hayat; Alevilik Üzerine Sosyolojik Bir Araştırma (Yayımlanmamış Doktora Tezi, Firat Üniversitesi, 2000), 141-145; Yahya Mustafa Keskin, Değişim Sürecinde Kırsal Kesim Alevîliği Elazığ Sünköy Örneği (Ankara: İlâhiyât Yayınları, 2004), 134-136; aynı yazar, Kentleşme Sürecinde Alevîlik Gelenek ve Modernizm Arasında Gelgitler -Elazığ Örneği (İstanbul: Kıvılcım Ajans, 2009), 159-164; Selçuk, Tahtacılar, 189; Özcan 
kasabalarda hatta ocak merkezlerinde dahi uygulamadan kalkmaya başlamıstır. Bunun temelinde ise Geleneksel Alevîlikte hakim olan boy-soy-aşiret sistemine dayalı sosyal yap1, bu sosyal yapiya uyarlanmış bir tasavvuf ve tarikat hayatı ve bu iki ana karakterin şekillendirdiği kapalı toplum olgusunun, modernite, sekülerleşme, sanayileşme, ssehirleşme, uzmanlık alanlarının belirginleşmesi, göç vb. etkenlere bağlı olarak köklü bir değişikliğe uğramasının yattığ değerlendirilmektedir. ${ }^{42}$

Alan araştırmalarında Musâhiblik kurumunun işletilememesinin sebepleri hakkında bir takım tespitlerde bulunulmuştur. Araştırma sonuçlarına göre bu konuda özellikle musâhiblerin birbirlerinin üzerinden çıkar sağlamaları; bazı kişilerin diğerlerinin sırtından geçinmeye başlamaları; bir takım olumsuzluklarla musâhibi düşkün ilan edilen kişilerin de düşkün ilan edilmesiyle suçsuz olan bu musâhib kardeşin söz konusu hali kaldıramamas1; bu kurumun yüklediği sorumluluğu kabullenmekten duyulan ağır yükle beraber, kırsal alanda yaşayan insanların şehir hayatı ve ekonomik dengenin bozulmasına bağlı olarak musâhiblerin birbirlerinden kopmaları; şehirleşme ve eğitim düzeyinin yükselmesinin yanı sıra gittikçe artan ekonomik zorlukların bu kurum ve gelenek üzerindeki olumsuz etkileri; giyecek ve diğer eşyalardan musâhib kardeşine de alınmak zorunda olunması, oysa günümüzde ekonomik olarak söz konusu zorunluluğu yerine getirmenin zorluğu/imkansızlığı; dedelerin etkilerinin azalması ve ikrâr alma törenlerinin de kalkması; hem Musâhiblik erkânı maliyetinin yüksek olması hem sonrasındaki sorumlulukların da ciddi bir maddî külfet getirmesi; bununla birlikte günümüzün hukukî ve sosyal şartlarında Musâhiblik kurumunun işleyişinin mümkün olmamas1, söz gelimi, birinin hatasından dolayı diğerinin de sorumlu olmasının günümüz hukuk düzeni ile uyuşmaması; kent ortamında farklı gruplarla yoğun bir biçimde temas halinde bulunmanın gelenekli

Güngör, Ârâf'taki Kimlik: Alevîlik/Bektâşilik (Ankara: Akasya Kitap, 2007), 258-261; H. İbrahim Bulut - Murat Çetin, "Gölyaka Alevîlerinin Dini İnanç Ve Yaşantıları", e-Makâlât Mezhep Araştırmaları, www.mezhep.org. $3 / 2$ (2010): 200; Ali Aktaş, "Kent Ortamında Alevîlerin Kendilerini Tanımlama Biçimleri ve İnanç Ritüellerini Uygulama Sıklıklarının Sosyolojik Açıdan Değerlendirilmesi”, I. Türk 5Kültürü ve Hacı Bektaş Veli Sempozyumu Bildirileri (Ankara: 1999): 459-460, 465; A. Faruk Sinanoğlu, Türk Kültüründe Alevi-Bektaşi Olgusu (Malatya Örneği) (İstanbul: IQ Kültür Sanat Yayıncılık, 2008), 147-150;Türkel, "Pîr Ahmed Efendi ve Alevîlik Anlayış1", 62; Üçer, Musâhiblik, 201-215.

42 Üçer, Musâhiblik, 220. 
tutumlarının değişiminde etkili olduğu vb. hususlara işaret edildiği görülmektedir. ${ }^{43}$

Ancak ülke gerçekliğinde geçmişte kırsal kesim şartlarında yaşayan Alevî geleneğe mensup kişilerin de ekonomik imkan açısından bugünden daha iyi olmadıkları az çok tahmin edilebileceğine göre, Musâhiblik kurumunun işlevsiz kalmasının değişen ekonomik şartlardan ziyade, öncelikle modernitenin etkisine bağlı olarak dünyada görülen genel bir zihniyet değişimine paralel ortaya çıkan aşırı bireyselleşme olgusuyla; daha sonra da yine modernitenin etkisiyle ortaya çıkan sanayileşme ve şehirleşmeyle bağlantılı olduğu açıktır. Dolayısıyla bireylere özel sorumluluklar yükleyen Musâhibliğin, dînî bir uygulama olarak ve sosyal işlevsellik açısından kaybolmaya yüz tutmasının, daha çok modernizm ve gittikçe artan sekülerleşmenin inançlar ve kurumlar üzerindeki etkileri ile irtibatlı olduğu görülmektedir. Aynı zamanda Musâhibliğin yükümlü tuttuğu sorumlulukların yerine getirilmesini zorlaştıran mevcut iktisâdî ve hukukî şartlar ile şehirleşme, göç vb. sosyal olay ve baskılar da bu kurumdaki dönüşümü daha doğru bir ifadeyle kurumun işlevsizleşmesini hızlandırmıştır. ${ }^{44}$

Bugün için şehirleşen Alevî geleneğin kurumsal yapılarına ait ayrıntılar da netlik kazanmış değildir. Başta Musâhiblik, Dedelik ve Düşkünlük gibi kurumların günümüz şartlarında ve sosyal ortamında nasıl var olacağı, uygulamalarda değişiklik mi olacağı ya da bütünüyle bunların ortadan $\mathrm{m}$ 1 kalkacağı zaman içerisinde şekillenecek olan hususlardır. Musâhibliğin kırsal hayat ve kapalı toplum şartlarının bir kurumu olduğu; günümüzde yaşatılamamasının şehirleşme ve açık toplum şartlarına bağlı olarak geleneksel yapıların sürdürülememesi gerçeğine dayandığ hususu bir yana, söz gelimi bu geleneksel yapı dişında açık toplum şartlarında şehirde Musâhiblik inşa edilecekse; musâhib kardeşlerin aynı ocaktan olması ya da aynı dernek ve vakfa üye olması mı esas alınacaktır, Musâhiblik erkânında hangi ocağın ya da derneğin usulleri takip edilecektir, bu erkânlar ocak dedelerince mi yoksa dernek ve vakıf dedelerince mi yürütülecektir, kardeş adaylarının aynı şehirde yaşaması mı esas olarak kabul edilecektir, aynı yaş grubundan olanlar $\mathrm{m} 1$ kardeş olabilecektir, meslek çeşitliliği dikkate alındığında meslekler arasında bu konu nasıl şekillendirilecektir, eğitim düzeyi değiştiğine göre gelenekteki alimcahil ayırımı, aynı seviyede eğitim görmüşler olarak m1 düzenlenecektir vb. pek çok husus açıklığa kavuşturulmayı beklemektedir.

43 Üçer, Musâhiblik, 218-219.

${ }^{44}$ Cengiz, Çamiçi Beldesinde Dini Hayat, 141-145. 
Yeni inşa sürecinde ocak farklılıkları, sahip olunan tasavvufî gelenek farklılıkları ve yöresel farklılıklar ile sözlü geleneğe bağlı olarak ortaya çıan karmaşık bilgilere ilaveten şehirde görülen örgüt çeşitliliği, bu inşa sürecini ve arayışları da zorlaştıran faktörlerdendir. 45

Geçmiște köken olarak göçebe, yarı göçebe ya da toprağa yeni yerleştirilmiş cemiyetlere has, sosyal nitelikli bir kurum olan ${ }^{46}$ ve cemaat yapisına sahip topluluklarda sosyal dayanışmayı, yardımlaşmayı ve güvenliği sağlayan bir olgu olarak ön plana çıkan ${ }^{47}$ Musâhibliğin, şehir şartlarında yeniden yapılandırılmadığ takdirde, Dedelik ve Düşkünlük türü geleneksel kurumlar gibi geçmişin düşsel ve tatlı bir anısı olarak sembolik bir değer taşımanın ötesinde bir anlamı olmayacağı açıktır. ${ }^{48} \mathrm{Bu}$ husus, geleneksel anlamda kırsal alanda ve ocak sisteminde şekillenen ve șehirlessmeyle birlikte özellikle büyük șehirlerde hemen hemen pratiği kaybolan Musâhibliğin, mevcut durumda șehir ortamında ve geleneksel kalıplar dışında inşa edilip edilemeyeceği ve bunun keyfiyetinin şekillenmesi açısından da önem taşımaktadır. ${ }^{49}$

\section{Alevî Nitelemeli Geleneğe Mensup Ocak ve Gruplar}

Anadolu'da yaşayan ve bugün itibariyle Alevî olarak isimlendirilen ocak ve grupların ortak özelliklerinden hareketle bir değerlendirme yapıldığında, Alevîliğin, genel hatlarıyla bir nevi "boysoy -aşiret" sistemine dayalı sosyal bir hayat sürdüren ve dînî hayatlarını daha çok tasavvuf ve tarikat hayatı kalıplarında şekillendiren topluluklar için bir üst kimlik veya bir şemsiye kavram olarak kullanıldığ görülmektedir. ${ }^{50}$ Boy-soy-aşiret sistemli sosyal bünyelerine uyarlayarak aldıkları sûfí karakterli İslâm anlayıșı, geçmişten günümüze Alevîlerin sadece dînî hayatını şekillendirmekle kalmamış, iman ve ibadet hayatı dahil her şeyi bu alana hasreden Alevî gelenek mensupları, daha çok göçebe ya da yarı göçebe veya kırsal bölgelerde sürdürdükleri sosyal hayatlarını

\footnotetext{
45 Üçer, "Musâhiblik Kurumu", 25-26.

46 Melikoff, Uyur İdik, 98.

47 Sarıkaya, Tarihî Arka Plan, 200-201; Eren Akın, "Kültürel Bellek Aktarımında Sosyal Örgütlenme ve Kontrol Mekanizması İlişkisi: Musahiplik Kurumu Örneği”, Alevilik-Bektaşilik Araştırmaları Dergisi 18 (2018): 303-309.

48 Harun Yıldız, "Alevî-Bektaşî Geleneğinde Musahiplik", Geçmişten Günümüze Alevî-Bektaşî Kültürü, edit. Ahmet Yaşar Ocak (Ankara: Kültür ve Turizm Bakanlığı Yayınları, 2009), 412.

49 Üçer, "Musâhiblik Kurumu", 25.

50 Üçer, Alevî Ocakları ve Grupları, 463.
} 
da yine tasavvuf ve tarikat hayatı kalıplarında şekillendirmiştir. ${ }^{51}$ Aslında Musâhiblik kurumu bu çerçeveyi teyit etmektedir. Nitekim Alevî geleneğe mensup kimi ocak ve gruplar bu ana karakter çerçevesinde, toplumsal yardımlaşma ve dayanışmayı sağlayan sosyal bir kurum olan Musâhibliği de tarikat hayatı kalıplarında anlamlandırıp biçimlendirmiş, bu bağlamda hem Musâhibliğin kuralları âdâb ve erkân kitaplarında açıklanmış, hem Musâhibliğe girecek olan kişilerin bu kavle girişleri bir tarikat ayini ya da erkânı ile gerçekleştirilmiş ve yine kurumun işleyişi de erkâna bağlanmıştır. $\mathrm{Bu}$ da, nihâî noktada Alevî nitelemeli geleneğe mensup ocak ve gruplarda hakim olan tasavvuf ve tarikat hayat1 gerçeğinin daha net görülmesini sağlamaktadır.

Alevîliğin Anadolu coğrafyasında Bektâşîler, Erdebil Sûfiyân Süreği Tâlibleri (Kızılbaşlar), Hubyarlılar, Dede Garkınlılar, Ağu İçenler, Baba Mansurlular, Keçeci Babalılar, Kureyşanlılar, Sinemilliler, Şücaaddin Velîliler, Tahtacılar vb. söz konusu toplulukları ifade etmek üzere bir üst kimlik ya da şemsiye kavram olarak kullanılması XIX. yy.1n ikinci yarısına ait bir gelişmedir. ${ }^{52}$ Hatta ülkemizde ve dünyada Alevî kelimesi söz konusu içerikle daha çok 1980-1990'lı yıllardaki gelişmelere bağlı olarak kullanılmaya başlanmıştır. ${ }^{53}$

Günümüzde daha çok Alevî nitelemesi ile anılan gelenek, gerek sosyal hayat gerek tarikat hayatı kalıplarındaki dînî yapı olarak "ocak sistemine" dayanmaktadır. Nitekim Alevî nitelemeli topluluklar kendi aralarında geleneksel anlamda metbu ocak olarak bilinen ana ocak ya da baş ocaklar etrafında teşkilatlanmış ve ana ocağa bağlı alt ocaklar oluşturmak suretiyle şekillendirdikleri söz konusu ocak sistemini günümüze kadar taşımıştır. ${ }^{54}$ Alevî nitelemeli topluluklarda ana ocak ve alt ocaklar yapıs1, kurumsal

51 Geleneğin tasavvufì boyutu hakkında ayrıca bkz. M. Saffet Sarıkaya, "AlevilikBektaşiliğin Tasavvufi Boyutu Üzerine", Türk Kültürü ve Hacı Bektaş Veli Araştırma Dergisi 82 (2017): 9-23.

52 Melikoff, Uyur İdik, 53; Hasan Onat, "Kızılbaşlık Farklılaşması Üzerine", İslâmiyât $7 / 3$ (2003): 124; Ömer Faruk Teber, "Osmanlı Belgelerinde Alevilik İçin Kullanılan Dini - Siyasi Tanımlamalar”, Anadolu'da Aleviliğinin Dünü ve Bugünü, edit. Halil İbrahim Bulut (Sakarya: Sakarya Üniversitesi Yayınları, 2010), 71. Konu hakkında isimlendirme, standartlaşma, anonimleşme gibi tartışmalar için bkz. Markus Dressler, Türk Aleviliğinin İnşast: Oryantalizm, Tarihçilik, Milliyetçilik ve Din Yazımı (İstanbul: İstanbul Bilgi Üniversitesi Yayınları, 2016).

53 Üçer, Alevî Ocakları ve Gruplar, 44-46.

54 Birdoğan, Anadolu ve Balkanlar'da Alevi Yerleşmesi; Ali Yaman, Alevilikte Dedeler Ocaklar (İstanbul: Ufuk Matbaac1lı, 1998); Hamza Aksüt, Aleviler Türkiye-İran-Irak-Suriye-Bulgaristan (Ankara: Yurt Kitap-Yayın, 2009); Ersal, Alevilik Kavramlar ve Ocak Sistemi. 
teşkilatlanma hali tekke yapılanmasına da etki etmiştir. Ana ocak ve bağlı alt ocaklar ya da bunun kurumsal teşkilatlanmış hali ana (metbu) tekke ve alt tekkeler şeklindeki yapı, sadece sosyal hayatla ilgili olmayıp daha çok tarikat hayatına dair uygulamaların hâkim olduğu dînî hayat da tamamen bu yapiya uyarlanarak yürütülmüştür. ${ }^{55}$

Alevî nitelemeli gelenek bütün unsurlarıyla söz konusu ocak yapılanmasına göre şekil almış ve varlığını bu sisteme göre bugüne kadar devam ettirmiştir. Geleneksel tekke yapılanması, silsileler, mensup olunan tasavvuf ekolleri, yürütülen âdâb ve erkân, yine âdâb ve erkân eserleri, Musâhiblik ve Düşkünlük gibi kurumların icrasında görülen farkliliklar aslında söz konusu ocak mensubiyetine dayanan farklılıklardır. Şehirleşmeyle ortaya çıkan gelişmelerin başlangıçta yine ocak sistemine göre şekil alması, şehirde artık anlayış birlikteliklerine göre oluşan kimliklere bağlı bir gruplassma olsa da son tahlilde bireylerin yine de ocak mensubiyetlerinin getirdiği etkilerden tamamen siyrılamaması ocak sisteminin Alevî geleneğe mensup topluluklar/ocaklar ve gruplar için dikkate alınması gerektiğini göstermektedir. ${ }^{56}$

$\mathrm{Bu}$ hususu Musâhiblik konusunun çizdiği çerçeve de teyit etmektedir. Nitekim Musâhiblik hakkında; yukarıda da işaret edildiği üzere Bektâşîlerce nasip alma olarak görülmesi, bazı ocaklarca tarikata giriş erkânı olarak algılanmas1, diğer bazılarınca ise tarikata giren ailelerden ikisinin ayrıca kardeşlik ahdi yapmaları şeklinde çok genel hatlarıyla 3 ayrı yaklaşım olmasının, söz konusu farklı ocak, mensup olunan farklı tasavvufì gelenekler ve farkl1 anlayışlar olgusundan kaynaklandığı açıktır. Uygulamaya dair kabullerin farklı olmasının yanı sıra Musâhiblik kurumunun ocaklar arasında değişik isimlerle adlandırılması da bunun açık göstergelerindendir.

\footnotetext{
55 Cenksu Üçer, "Alevî Nitelemeli Gelenek ya da Ocak ve Gruplar Hakkında Yapılacak Calıșmalarda Ocak Sisteminin Dikkate Alınmasının Önemi”, $e$ makâlât 12/2 (2019): 362-370. Amasya, Adiyaman ve Ankara Çubuk havzasındaki ocaklar için bkz. Harun Yıldız, "Amasya Yöresinde Alevîlik: Ocak ve Yapılar", Uluslararası Amasya Sempozyumu: Tarih-Dil-KültürEdebiyat 2 (2017), 1527-1555; Fevzi Rençber, "Adıyaman Yöresi Alevî Ocakları", OMÜ İlahiyat Fakültesi Dergisi 35 (2013): 159-170; Ersal, Alevilik Kavramlar ve Ocak Sistemi, 63.

56 Üçer, “Ocak Sisteminin Dikkate alınması”, 382-389.
} 


\section{Din Kültürü Ahlak Bilgisi Müfredatında Musâhiblik Konusunun Yer Almasi}

1960'l1 yıllardan 1980'l1 y1llara, o yıllardan da bugüne dünyada ve ülkemizde yaşanan bir takım sosyal ve siyâsî gelişmelere bağlı olarak bir kimlik politikası olgusu ortaya çıkmıştır. ${ }^{57} \mathrm{Bu}$ bağlamda ortaya çıkan kimlik politikası olgusundan, geçmişte her biri Ağuçan, Baba Mansur, Hacı Bektaş, Dede Garkın, Hasan Dede, Keçeci Baba, Hubyar, Şücaaddin Veli vb. mensup olduğu ocak ismiyle anılan toplulukların da etkilenmiş olduğu hususunda şüphe yoktur. ${ }^{58}$ Yaşanan gelişmeler bir takım değişim ve dönüşümlere neden olmuştur. ${ }^{59}$ Nitekim bu süreçte "bir Alevî kimliği" görünürlük kazanmış ve yukarıda da işaret edildiği üzere bahse konu ocak mensupları için bir şemsiye kavram olarak daha çok Alevî nitelemesi ve isimlendirilmesi kullanılmaya başlanmıştır. ${ }^{60}$ Yine ülkemizde görülen paralel gelişmeler çerçevesinde bu dönemde artık günümüzde kendilerine daha çok Alevî nitelemesi kullanılan söz konusu ocak ve gruplarla ilgili dînî, sosyal ve siyâsî alanlarda farklı konu başlıkları tartış1lmıştır. ${ }^{61}$

Son zamanlara kadar dînî, sosyal ve kültürel açılardan ülke gündeminde canlılığını muhafaza eden Alevî gelenek ya da mensupları hakkında uluslararası boyutta da bir takım tartışmalar ve süreçler yaşanmıştır. Söz gelimi, Alevî gelenek ve mensupları, Avrupa Birliği süreciyle bağlantılı olarak yürütülen bazı tartışmalara inanç farklılıkları (!) boyutuyla taşınmış, bir takım

57 Hakan Bayri, Türkiye'de Kimlik Siyaseti Sorunu ve Ulusal Kimlik (1980 Sonrası Döneme Sosyo-Politik Bir Bakış) (Doktora Tezi, Atatürk Üniversitesi, 2008), 23.

58 Sönmez Kutlu, "Aleviliğin Dinî Statüsü: Din, Mezhep, Tarikat, Heterodoksi, Ortodoksi veya Metadoksi", İslâmiyât $7 / 3$ (2003): 51-52; Hasan Onat, "Kimlik Teoloji İlişkisi Bağlamında Alevîlik-Bektaşîlikle İlgili Kimlik Tartışmaları Üzerine", Alevilik-Bektaşilik Araştırmalar Dergisi 1 (2009): 22-25; Necdet Subaş1, Alevilik Çalıştaylarn Nihai Raporu (Ankara: 2010), 56, 61-64.

59 Sönmez Kutlu, Çăgdaş İslamî Akımlar ve Sorunları (Ankara: Fecr Yayınları, 2008), 10; Necdet Subaş1, "Türk Modernleşmesi ve Alevîler", Geçmişten Günümüze Alevî-Bektaşî Kültürü, edit. Ahmet Yaşar Ocak (Ankara: Kültür ve Turizm Bakanlığı Yayınları, 2009), 110; Abdullah Alperen, "Alevî(lik) Modernleşmesine Dair Düşünceler”, Dem Dergi 2/ 6 (2009): 76, 79.

60 Anadolu'da söz konusu ocak ve gruplar için Alevî nitelemesinin kullanılmaya başlanması hakkında bkz. İrene Melikoff, Uyur İdik, 53; Onat, "Kızılbaşlık Farklılaşması Üzerine”, 124; Üçer, Alevî Ocakları ve Grupları, 43-45.

61 Söz gelimi Alevî gelenek mensuplarının Diyanet'ten beklentileri hakkında bkz. Metin Bozkuş, "Alevî Yurttaşlara Yönelik Dinî Hizmetlerin İcrası Bağlamında Bir Teklif Denemesi”, Cumhuriyet Üniversitesi İahiyat Fakültesi Dergisi 10/1 (2006): 1-12. 
ülkelerce yayımlanan raporlarda yer almış ve Avrupa İnsan Hakları Mahkemesi (AİHM) davalarına konu olmuştur.

Türkiye'de 2000'li yıllardan itibaren demokratiklessme adımlarına hız verilmesi, farklı inanç ve kanaatlerin de kendini ifade etmesine ve aynı zamanda sorunlarını daha açı bir şekilde ortaya koymasına imkan tanımıștır. 2009 yılında başlayan Alevi Açılımı adıyla yürütülen çalışmalarla Alevi ismi altında örgütlenen kurulusslar ve devletin yetkili birimleri aynı masanın etrafında buluşmuş, sorunlar objektif bir şekilde masaya yatırılmaya çalış1mıştır. ${ }^{62}$ Bütün bu gelişmelerin pratik bir karş1lığ olarak, 1990'1 yıllardan 2010'lu yıllara yapılan alan araştırmalarının ortaya koyduğu verilerin de gösterdiği üzere ${ }^{63}$ farklı yönleriyle tartışılan DKAB derslerinde64 Alevîlik konusunda bir takım bilgilere yer verilmiştir. ${ }^{65}$ Aslında 2005 yılından itibaren Alevî gelenek açısından önemli görülen bir takım kavram ve konular DKAB dersinin müfredat1 içerisinde yer almaya başlamıștır. ${ }^{66} \mathrm{Bu}$ süreçte Alevî geleneğe ait konuların DKAB müfredatında farklı sinıflarda yer aldığ $1^{67}$ bilinmekle birlikte bugün itibariyle ilgili konular İlköğretim ve Ortaöğretimde değişik sınıflarda işlenmektedir.

62 Necdet Subaş1, Alevilik Çalıştaylar Nihai Raporu (Ankara: 2010), 2-3. Aç1lım Çalışmaları esnasında yapılan bir takım kimlik tartışmaları hakkındaki bazı değerlendirmeler için bkz. Hasan Onat, "Açılım Arayışlarının Gölgesinde Alevilik-Bektaşilik ve Kimlik Tartışmaları", Dinî Araştırmalar 12/33 (2009): 40-43.

63 Eyup Şimşek - Özcan Güngör, "Alevi Yapısallaşması, Talepler Ve Din Kültürü Ve Ahlak Bilgisi Ders Kitaplarında Alevilik-Bektaşilik", Turkish Studies 8/3 (2013): 543-545.

64 Farklı inanç grupları ve din eğitimi hususunda konunun farklı yönlerine dikkat çeken bir çalışma için bkz. Sönmez Kutlu, "Farklı İnanç Grupları ve Din Eğitimi”, Kişisel. Sönmez Kutlu, erişim: 01 Haziran 202. http:/ / www. sonmezkutlu.net/?Syf=26\&.Syz $=6026 \& /$ Farkl\%C4\%B1$\%$ C4\%B0nan\%C3\%A7-Gruplar\%C4\%B1-ve-Din-E\%C4\%9Fitimi.

65 İbrahim Turan, "Din Kültürü ve Ahlak Bilgisi Öğretmenlerinin Aleviliğin Öğretimi ile İlgili Yeterlik Algıları", Hitit Üniversitesi Sosyal Bilimler Enstitüsü Dergisi 10/2 (2017): 880. Bu konuda dile getirilen teklifler hakkında Alevîlik Çalıștayları Nihai Raporunun ilgili kısımlarına (s. 192-193, 15-21. maddeler) bakilabilir.

66 Hüseyin Yılmaz, "Alevîlik-Sünnîlik Açısından Din Kültürü ve Ahlak Bilgisi Dersleri”, Cumhuriyet Universitesi Ilahiyat Fakültesi Dergisi 13/2 (2009): 199203; Halise Kader Zengin, "Din Kültürü Ve Ahlak Bilgisi Dersi Öğretim Programlarında Devletin Alevilik Algısı (Karşılaştırmalı Bir Analiz)", Elektronik Sosyal Bilimler Dergisi 12/47 (2013). 65-66.

67 Serderhan Musa Taşkaya, "Din Kültürü ve Ahlak Bilgisi Ders Kitaplarında Alevilik-Bektaşilik", 2. Uluslararası Türk Kültür Evreninde Alevilik Ve Bektaşilik Bilgi Şöleni Bildiri Kitabı, edit. Filiz Kılıç - Tuncay Bülbül (Ankara: Gazi Üniversitesi Türk Kültürü ve Hacı Bektaş Veli Araştırma Merkezi 
Bu çalışmada, gerek 7. gerek 12. sınıf müfredatında yer alan Musâhiblik konusu ele alınmaktadır.

Millî Eğitim Bakanlığı Talim ve Terbiye Kurulu'nun resmî internet sayfasında 7. sınıfın İslam Düşüncesinde Yorumlar başlıklı 5. ünitesinde 4. kazanım "Alevilik-Bektaşilikle ilgili temel kavram ve erkânları açıklar." 68 şeklinde yer almaktadır. İlgili kazanım hakkında "Cem ve cemevi, musahiplik, razılık ve kul hakkının sorulmas1, cemde on iki hizmet, semah, gülbank, Hızır ve Muharrem orucuna ve uygulanma şekline yer verilir. Bu kapsamda; Alevilik-Bektaşilikteki 'ocak kültürü'ne ve 'el ele, el hakka ikrarı'na yer verilir; Bektaşilikte musahipliğe 'ikrar ve nasip alma' da denildiğine ve bu kavramın İslam tarihindeki muhacir ensar kardeşliğine dayandırıldığına değinilir." açıklaması yapılmaktadır.

Millî Eğitim Bakanlığı Talim ve Terbiye Kurulu'nun resmî internet sayfasinda 12. sinıfin İslam Düşüncesinde Tasavvufi Yorumlar başlıklı 3. ünitesinde 4. kazanım "Alevilik-Bektaşilikle ilgili temel kavram ve erkânları tanır." 69 şeklinde yer almaktadır. Bu dersin kazanımı hakkında da "Cem ve cemevi, musahiplik, razıllk ve kul hakkının sorulması, cemde on iki hizmet, semah, gülbank, Hızır ve Muharrem orucuna ve uygulanma ssekline yer verilir. $\mathrm{Bu}$ kapsamda; Alevilik-Bektaşilikteki 'ocak kültürü'ne ve 'el ele, el hakka ikrarı'na yer verilir; Bektaşilikte musahipliğe 'ikrar ve nasip alma' da denildiğine ve bu kavramın İslam tarihindeki muhacir ensar kardeşliğine dayandırıldığına değinilir." şeklinde 7 . sınıftakine benzer bir açıklama yapıldığı görülmektedir.

$\mathrm{Bu}$ konular Milli Eğitim Bakanlığı bünyesinde 7. sınıflarda Sadullah Macit tarafindan yazılan ve Talim ve Terbiye Kurulu Başkanlığının 18.04.2019 tarihli ve 8 sayılı kurul kararı ile 2019-

Yayınları, 2007), 1/475-497; Yılmaz, "Alevîlik-Sünnîlik Açısından Din Kültürü ve Ahlak Bilgisi Dersleri", 201-203; Hasan Yücel Başdemir, "Din Dersleri ve Aleviliğin Aktarılması", Liberal Düşünce 16/63 (2011): 64-67; Zengin, "Devletin Alevilik Algısı", 67-84; Şimşek - Güngör, "Alevi Yapısallaşması", 548-554. Taşkaya'nın makalesinde Şîiliğe ait bazı kavram ve isimlerin de konu bağlamında listelenmesi Mezhepler Tarihi açısından değerlendirmeyi gerektiriyor olsa da, o dönemde konular arasında Musâhibliğin yer almaması dikkat çekmektedir. Zengin'in tespit ettiği üzere Musâhibliğin 2010 programlarında gündeme girmeye başladığı görülmektedir.

$68 \mathrm{http}: / /$ mufredat.meb.gov.tr/Programlar.aspx. Erişim: 02.06.2020.

file:///C:/Users/Casper-Pc/Downloads/2018130153652546-DKAB_(48.\%20S\%C4\%B1n\%C4\%B1f)_DOP_\%202018.pdf.

$69 \mathrm{http}: / /$ mufredat.meb.gov.tr/ProgramDetay.aspx?PID=319. Erişim: 02.06.2020. file:///C:/Users/Casper-Pc/Downloads/201813015378536-DKAB_(9$12 . \% 20 \mathrm{~S} \% \mathrm{C} 4 \% \mathrm{~B} 1 \mathrm{n} \% \mathrm{C} 4 \% \mathrm{~B} 1 \mathrm{f}) \_20 \mathrm{DOP} \% 202018$.pdf. 
2020 Öğretim Yılından itibaren 5 (beş) yıl süreyle ders kitabı olarak kabul edilen ${ }^{70}$ kitap; 12 siniflarda ise Feramuz Yilmaz ve arkadaşları tarafından yazılan ve Talim ve Terbiye Kurulu Başkanlığının 25.06.2018 tarihli ve 12254648 sayılı yazısı ile eğitim arac1 olarak kabul edilen ${ }^{71}$ kitap arac1lıyla öğrencilere aktarilmaktadır.

7. sınıf kitabında "insanın olgun bir kişiliğe sahip olması için öncelikle kendisine bir musahip edinmesi gerektiğine işaret edilerek konuya başlanmış ve musahibin "yol arkadaşı" demek olduğu dile getirilmiştir. Daha sonra 'Alevilik-Bektâşîlikte, evli olan iki çiftin, pir huzurunda ikrar verip yol kardeşi olmalarına musahiplik denildiği'ne işaret edilmiştir. Devamında 'musahibliğin gerçekleşmesi için musahiplik cemi adı verilen bir tören' yapılacağı, bu cemde pirin huzurunda ikrar verildiği için bu cemin ikrar cemi olarak bilindiği' ifade edilerek, 'Alevilik-Bektaşilikte musahipliğe ikrar ve nasip alma da denildiği"ne işaret edilmiștir.

Kitapta konu hakkında Bilgi Notu kısmında Derviș Tur ve Hüseyin Dedekargınoğlu'ndan alıntılar yapılarak 'Musahipliğin amacına ulaşabilmesi ve sağlıklı yürümesi için bazı şeylere önem verilmesi gerektiği'nden bahisle 'musahip olan çiftlerin birbirini iyi tanıması, inançta, fikirde, ilim ve kültürde birbiriyle aynı seviyede olmas1, birbirini sevmesi ve saymas1, birbirlerinin yanında olmas1, iyilik ve kötülük konusunda birbirlerini uyarmas1, maddi ve manevi anlamda birbirlerinin sigortas1 olmas1, bu itibarla birbirlerine her zaman ulaşabilecek kadar yakın oturmaları' gerektiği üzerinde durulmuştur.

Devaminda 'musahip olmak isteyen kişilerin bu isteklerini pire iletecekleri, pirin dileklerini uygun görürse kendilerine şartları ve kuralları ayrıntılı bir şekilde anlatıp onları test etmek için en az bir yıllık deneme süresi verdiği' anlatılmış, ana hatlarıyla ve kısaca bir Musâhiblik Cemine yer verilmiştir. ${ }^{72}$

Kitapta Musâhibliğin Hz. Peygamber'in (sas) Mekke'den Medine'ye gelen Muhâcirler ile Medineli Ensar arasında tesis ettiği kardeşlik olayına dayandırıldığına işaret edilerek Musâhiblik andlaşması yapıldıktan sonra musâhib kardeşlerin "birbirlerinin evine teklifsiz gireceği, yemeğini teklifsiz yiyeceği; birbirinden saklı gizli işleri olmaması gerektiği, kazançlarının bir olması gerektiği vb.'

\footnotetext{
70 Sadullah Macit, Ortaokul ve İmam Hatip Ortaokulu Din Kültürü ve Ahlak Bilgisi Ders Kitabı (İstanbul: FCM Yayınc1lık, 2019), künye sayfası.

${ }^{71}$ Feramuz Y1lmaz v.dğr. Ortaöğretim Din Kültür ve Ahlak Bilgisi (Ankara: Devlet Kitaplar1, 2018).

72 Macit, Ders Kitabr, 122-123.
} 
birbirlerine nasıl davranacaklarına dair bir Bilgi Notunu Cafer Sadık Buyruğu'na atıfla yer vererek konunun bitirildiği görülmektedir. ${ }^{73}$

12. sınıf ders kitabında sözlükte 'kardeş tutmak, kardeş edinmek' anlamına gelen musahipliğin 'Alevilik-Bektaşilikte evli olan iki kişinin essleriyle birlikte, kurban keserek hayat boyu yol kardeşi olmaya Hakkın ve halkın huzurunda ikrar vermesidir.' şeklinde tanımlandığı ve Bektâşîlikte bunun 'ikrar ve nasip alma olarak ifade edildiği'ne değinildiği görülmektedir.

Devaminda bunun Kur'an ayetleri (Hucurât, 10; Enfâl 72) ve hicretle kurulan kardeşlik (muâhât) uygulamasına dayandığ vurgulanarak $\mathrm{Hz}$. Peygamber'in (sas) kendisine $\mathrm{Hz}$. Ali'yi kardeş seçtiği ifade edilip kardeş yapılan diğer sahabeden (Selman-1 Fârisî, Ebu'd-Derdâ, Eyyüb el-Ensârî gibi) örnekler verilmiștir.

Daha sonra kitap, 'musahipliğin ömür boyu' sürdüğünü dile getirip, bir Buyruk nüshasından (Fuat Bozkurt) alıntıyla Dedenin musâhib olanlara verdiği "birbirinden malı esirgememek, aralarında tartışıp dargın düşmemek, yalan söylememek, haram yememek, zina etmemek, dedikodu etmemek, elinle koymadığını almamak, gözünle görmediğini dememek, kimseyi incitmemek vb.” hususları muhtevi öğütle konuyu devam ettirmektedir. ${ }^{74}$ 'Musahiplik erkânında talip olana verilen' benzer öğütlere Ömer Uluçay’ın eserinden alıntıyla devam eden kitap konuyu Pir Sultan Abdal'dan bir deyişle bitirmektedir. ${ }^{75}$

\section{Değerlendirme}

Çalışmamızın bu kısmında Musâhiblik ve Alevî geleneğe mensup ocak ve gruplar hakkında yukarıda çizilen çerçeveyle konunun ders kitaplarında işlendiği çerçeve mukayese edilerek değerlendirme yapılmıştır. Bu meyanda mümkün mertebe ders kitaplarında paylaşılan bilgiler dikkate alındığında şu hususlar göze çarpmaktadır:

7. sınıf kitabında insanın olgun bir kişiliğe sahip olması için öncelikle kendisine bir musahip edinmesi gerektiğine işaret edilmektedir. Musâhiblik bütün ocaklarda olmadığına göre ve olanlarda da farklı anlamlandırmalar olduğuna göre, bu ifadenin bu şekliyle yer alması gelenekteki uygulama açısından doğru değildir.

Kitapta musâhibin "yol arkadaşı" demek olduğu dile getirilmektedir. Ancak burada kelime anlamı mi terim anlamı m1

\footnotetext{
73 Macit, Ders Kitabr, 123.

74 Y1lmaz vd., Ortaöğretim Din Kültür ve Ahlak Bilgisi, 84.

75 Y1lmaz vd., Ortaöğretim Din Kültür ve Ahlak Bilgisi, 85.
} 
üzerinde durulduğu net olarak anlaşılmamaktadır. Kelime anlamına "yol" ifadesi eklenerek sonrasinda hemen terim anlamı ve mahiyeti verildiği için kitapta terim anlamını çağrıştıracak bir tercihte bulunulduğu değerlendirilmektedir. Ancak bunun yukarıda kelimenin anlamlarına dair verilen çerçeveyle uyuşmadığı göze çarpmaktadır. Ayrıca terim olarak verdiği tanımda "yol kardeşi" ifadesinin kullanılması metinde bir karışıklığa neden olmaktadır.

"Alevîlik-Bektâsîlikte, evli olan iki çiftin, pir huzurunda ikrar verip yol kardeşi olmalarına musahiplik denildiği"ne işaret edilmektedir. $\mathrm{Bu}$ noktada birkaç ayrı husus dikkat çekmektedir. Birincisi Alevilik-Bektaşilik kullanımı: Bu hem akademik dünyanın hem popüler yazın dünyasının, ocak sistemini dikkate almadıkları için sıkça kullandıkları bir nevi galat-1 meşhur bir ifade haline gelmiştir. Kitap bunu kullanmaktan kendini alıkoyamamıştır. Ancak biraz sonra 'Alevilik-Bektaşilikte musahiplik ve nasip alma' adına söylemeye çalıştığı ifadeler konuyu karmaşıklaștırmaktadır. İkincisi, verilen tanım, Musâhiblik adına ortaya konulan anlamlandırmalar ve uygulamalardan sadece birisine işaret etmektedir. Musâhiblik adına ortaya konulan ve yukarıda işaret edilen farklı diğer uygulamalar haliyle kapsam dışında kalmaktadır. Üçüncüsü, 'evli olan iki çiftin ikrar verip yol kardeşi olmaları' ifadesi, yukarıda değinilen Musâhiblik uygulamalarından, ikrârla yola girmenin Musâhiblik erkânıyla yapıldığı uygulamayı mı; yoksa zaten ikrar vererek yola girmiş iki evli ailenin Musâhiblik erkânıyla musâhib kardeş olmaları şeklindeki uygulamayı mı kasdettiği net olarak anlaşılmamaktadır.

'Musahipliğin gerçekleşmesi için musahiplik cemi adı verilen bir tören yapılacağı, bu cemde pirin huzurunda ikrar verildiği için bu cemin ikrar cemi olarak bilindiği' ifade edilmektedir. Bu ifadeyle kitabın Musâhiblik ikrarıyla yola girmenin esas aldığı uygulamaya daha çok işaret ettiği anlaşılmaktadır. Bu durumda diğer uygulamaların yine dışarıda kaldığı anlaşılmaktadır.

'Alevilik-Bektaşilikte musahipliğe ikrar ve nasip alma da denildiği'ne değinilmektedir. Kazanımlarda 'Bektaşilikte musahipliğe ikrar ve nasip alma da denildiği' ifade edilerek Bektaşîlikte diğer ocaklardaki gibi kurumsal bir işleyişin olmadığına işaret edilmiş iken; kitabın bu ayrıntıyı kaçırdığı görülmektedir.

Kitapta konu hakkında Bilgi Notu kısminda Derviş Tur ve Hüseyin Dedekargınoğlu'ndan alıntılar yapılarak 'Musahipliğin amacına ulaşabilmesi ve sağlıklı yürümesi için bazı şeylere önem verilmesi gerektiği'nden bahisle "musahip olan çiftlerin brbirini iyi tanıması, inançta, fikirde, ilim ve kültürde birbiriyle aynı seviyede olmas1, birbirini sevmesi ve saymas1, birbirlerinin yanında olmas1, 
iyilik ve kötülük konusunda birbirlerini uyarmas1, maddi-manevi birbirlerinin sigortas1 olmas1, bu itibarla birbirlerine her zaman ulaşabilecek kadar yakın oturmaları' gerektiği üzerinde durulmaktadır. Musâhibliğin geleneksel olarak kurumsal bir yapıda yürütüldüğü ocaklarda bu şartların üzerinde durulduğu bilinmektedir. $\mathrm{Bu}$ itibarla bu bilgilerin evli çiftlerin ayrıca Musâhiblik erkânıyla kardeş ilan edildikleri uygulamalar açısından doğru olduğu görülmektedir.

Kitapta Musâhibliğin Hz. Peygamber'in (sas) Mekke'den Medine'ye gelen Muhâcirler ile Medineli Ensar arasında tesis ettiği kardeşlik olayına dayandırıldığına işaret edilmektedir. Bu noktada da birkaç husus dikkat çekmektedir. Gelenekte gerek kaynaklarda gerek müntesipler arasında Musâhiblik kurumunun dayanağ hakkında farklı temellendirmeler yapıldığı malumdur. Kitabın bunlardan sadece birine vurgu yaptığı görülmektedir. Bu bir yönüyle doğru diğer yönüyle eksik bir bilgi olmakla beraber yaygin olan görüş ve kanaatler bu yönde olduğu için ve konuyu somut olgu ve olaylarla anlatma imkanı açısından tercih edilmesi kuvvetle muhtemel görünmektedir.

Musâhiblik andlaşması yapıldıktan sonra musâhib kardeşlerin 'birbirlerinin evine teklifsiz gireceği, yemeğini teklifsiz yiyeceği; birbirinden saklı gizli işleri olmaması gerektiği, kazançlarının bir olması gerektiği vb.' birbirlerine nasıl davranacaklarına dair bir Bilgi Notunun Cafer Sadık Buyruğu'na atıfla yer vererek konunun bitirildiği görülmektedir. Bu noktada işaret edilmesi gereken temel sıkıntı, Alevî nitelemeli geleneğe ait âdâb ve erkâna dair eserlerin sanki bütün ocak ve gruplar için ortak müracaat kaynakları olarak görülmek istenmesidir. Yukarıda ocak sisteminde işaret edilmeye çalışıldığı üzere, her ocağın âdâb ve erkânına ait eserler o ocakların kendi gelenekleri ve bağll11kları anlamında kendilerine aittir ve her ocak aslında kendi âdâb ve erkân eseriyle amel eder. Burada ifade edilmeye çalış1an hususun anlaşılması adına Cafer Sadık Buyruğu'ndan hareketle somut bir söz söylemek gerekirse, Cafer Sadık Buyruğundaki yaklaşımlar bu Buyruk nüshasını kabul eden gruplardaki yerleşik anlayışları ifade eder. Bu itibarla bir gruba ait eserde ifade edilen bir hususu bütün gruplara teşmil etmek ocak sisteminin izin vermeyeceği bir durumdur. ${ }^{76}$

Musâhiblik hakkında kaynaklarda yer alan ve gelenek mensuplarınca da değinilen musâhib kardeşlerin karşıllklı sorumluluklarına dair hususların, günümüz şartlarında yerine getirilmesindeki güçlükler ve imkansızlıklar nedeniyle kalkmaya

76 Üçer, “Ocak Sisteminin Dikkate Alınması”, 386. 
başladığı; hatta Musâhiblik kurumunun var olduğu ocaklarda -ocak merkezlerinde dahi- artık Musâhiblik uygulamaların iyice zayıflayıp pratikten kalktığının dile getirildiği bir gerçeklikte, bunların özellikle de 7 . sınıf öğrencilerine- öğretilmesinin pedagojik açıdan alan uzmanlarınca değerlendirilmesi gerektiğinde şüphe yoktur.

'Musahip olmak isteyen kişilerin bu isteklerini pire iletecekleri, pirin dileklerini uygun görürse kendilerine şartları ve kuralları ayrıntılı bir şekilde anlatıp onları test etmek için en az bir yıllık bir deneme süresi verdiği'nin anlatıldığı görülmektedir. Bu gerek Musâhiblik erkânıyla ikrar vererek yola giren gerek ikrâr verip yola girdikten sonra Musâhiblik erkânıyla kardeş ilan edilen evli çiftler için gelenekte uygulanan bir husustur.

12. sınıf ders kitabındaki bilgilerin değerlendirilmesine gelince: Bu kitapta da "kardeş tutmak, kardeş edinmek" şeklinde verilen kelime manasının terim anlamına işaret edecek şekilde bir tercihle verildiği anlaşılmaktadır.

Musahiplik 'Alevilik-Bektaşilikte evli olan iki kişinin eşleriyle birlikte, kurban keserek hayat boyu yol kardeşi olmaya Hakkın ve halkın huzurunda ikrar vermesidir.' şeklinde tanımlanmaktadır. Burada da evli iki kişinin Musâhiblik erkânıyla ikrar vermesi mi yoksa zaten ikrârlı olan iki ailenin düzenlenen bir erkânla Musâhiblik kavline girmeleri mi kastedildiği tam olarak anlaşılmamaktadır.

Bektâşîlikte Musâhibliğin 'ikrar ve nasip alma olarak ifade edildiği'ne değinilmektedir. 12. Sinıf kitabında 'Bektaşilikte musahipliğe ikrar ve nasip alma da denildiği' ifade edilerek kazanımda işaret edilen hususa uygun hareket edildiği görülmektedir. Böylelikle Bektaşîlikte diğer ocaklardaki gibi kurumsal bir işleyişin olmadığına işaret edilmiş olmaktadır.

Musâhibliğin Kur'an ayetleri ve hicretle kurulan kardeşlik (muâhât) uygulamasina dayandığının vurgulanarak $\mathrm{Hz}$. Peygamber'in (sas) kendisine Hz. Ali'yi kardeş seçtiği ifade edilip kardeş yapılan diğer sahabeden (Selman-1 Fârisî, Ebu'd-Derdâ, Eyyüb el-Ensârî gibi) örnekler verilmektedir. Burada yine Musâhibliğin kökeni hakkında farklı kabullerden yaygın ve somut olguya dayalı olanının tercih edildiği; olgunun müşahhas örneklerle teyit edildiği görülmektedir.

'Musahipliğin ömür boyu' sürdüğü dile getirilmektedir. Bu Musâhiblik kurumunun yaşatıldığı bütün ocaklardaki genel kabule uygundur.

Bir Buyruk nüshasından (Fuat Bozkurt) alıntıla Dedenin musâhib olanlara verdiği "birbirinden malı esirgememek, aralarında 
tartışıp dargın düşmemek, yalan söylememek, haram yememek, zina etmemek, dedikodu etmemek, eliyle koymadığını almamak, gözüyle görmediğini dememek, kimseyi incitmemek vb.” hususları muhtevi öğütle konu devam ettirilmektedir. Bu tür öğütlerin Musâhiblik erkânının uygulandığı geleneksel yapılarda dile getirilen hususlarla uyuştuğu görülmektedir. Ancak devamında 'musahiplik erkânında talip olana verilen benzer öğütlere Ömer Uluçay'ın eserinden alıntıyla devam ederken konu bütünlüğünde musâhib ve tâlib kavramlarının zihinlerde karıșıklığa neden olduğu anlaşılmaktadır. Ayrıca kitapların her ikisindeki metinler, Musâhibliğin sadece tâlibler arasında kurulan bir kardeşlik andlaşması olduğu yönünde bir kanaatin oluşmasına sebep olmaktadır. Halbuki gelenekte sadece tâlibler değil; dede soylu kişilerin de musâhib kardeş tuttukları bilinmektedir.

Konunun Pir Sultan Abdal'dan bir deyişle bitirilmesi gelenek açısından uygun olmuştur. Kitapta deyişte geçen bazı kelimelerin açıklamalarının verilmesi de yerinde olmuştur.

\section{Sonuç}

Alevî nitelemeli geleneğe mensup kimi ocak ve gruplarda var olan Musâhiblik, farklı anlayış ve uygulamalar olmakla birlikte yaygın kabule göre, kan bağı taşımayan evli iki ailenin dünya ve ahiret kardeşliğini ifade eden sosyal yardımlaşma ve dayanışma merkezli kurumsal bir yapıdır. Musâhibliğin, Anadolu'da toplumsal yardımlaşma ve dayanışma fonksiyonu icrâ eden Yaren, Barana, Delikanlı Teşkilatı gibi pek çok oluşumda görülen anlayış ve ilkelerin, Alevî nitelemeli ocak ve grupların sosyal ve dînî hayatına göre hal almış bir şekli olduğu anlaşılmaktadır. Alevî nitelemeli ocak ve grupların sosyal ve dînî hayatının ise bir nevi boy, soy, aşiret sistemi ve kırsal hayat şartlarına uyarlanmış bir tasavvuf ve tarikat hayatı kalıplarında şekillendiği görülmektedir.

Alevî geleneğe mensup ocak ve gruplarda hakim olan boy-soyaşiret sistemine dayalı sosyal yap1, bu sosyal yapıya uyarlanmış bir tasavvuf ve tarikat hayatı ve kırsal şartlarda bu iki ana karakterin şekillendirdiği kapalı bir toplum olgusu, modernite, sekülerleşme, sanayileşme, şehirleşme, uzmanlık alanlarının belirginleşmesi, göç vb. etkenlere bağlı olarak köklü bir değişikliğe uğramıştır. Bunun sonucunda Musâhiblik başta olmak üzere Dedelik ve Düşkünlük gibi geleneksel olgu içerisinde anlam bulan ve şekillenen anlayış ve kurumsal yapılar kökten sarsılmış ve geçmişte Alevî geleneğe mensup toplulukların disiplinli yapısını korumada ve toplumsal dayanışma ve yardımlaşmayı sağlamada önemli roller üstlenmiş olan bu kurumlar, günümüzde işlevini yitirmiş ve unutulmaya yüz tutmuştur. 
Gelişmelere bağlı olarak günümüzde Musâhiblik, gerek şehirde gerek köy ve kasabalarda ideal anlamıla yaşatılamamaktadır. Musâhiblik köy ve kasabalarda hatta ocak merkezlerinde dahi iç işleyişteki aksaklıklar dolayısıyla uygulamadan kalkmaya başlamıştır. Geleneksel anlamda kırsal alanda ve ocak sisteminde şekillenen ve şehirleşmeyle birlikte büyük şehirlerde hemen hemen pratiği kaybolan Musâhibliğin, özellikle şehir ortamında ve geleneksel kalıplar dışında inşa edilip edilemeyeceği ve bunun gerek şehirlerde gerek kırsalda keyfiyetinin nasıl şekilleneceği merak konusu olmaya devam etmektedir.

Dünyada ve ülkemizde yaşanan gelişmelere bağlı olarak gerek kırsaldaki ocak ve gruplarda gerek şehirleşmeyle şekillenen gruplarda işlevini yitirmiş bulunan Musâhiblik kurumunun, yine yaşanan gelişmeler paralelinde 2010'lu yıllardan itibaren DKAB derslerinde 7 . ve 12 . sınıf ünitelerinde müfredata eklendiği görülmektedir.

Gelenek içerisinde dahi farklı farklı anlayış ve uygulamaların olduğu bir konunun müfredatta yer alı-almaması hususunun, öğrencilerin -özellikle 7 . sinıf - zihinsel gelişimleri ve dînî anlayış farklılıklarını kavrayış düzey ve imkanları göz önünde bulundurularak Bakanlığımızın yetkili birim ve kurulları ile alan uzmanlarınca değerlendirilmesi gerektiğinde şüphe yoktur.

Müfredatta Musâhiblik konusunun ele alınışına gelince Musâhiblik, öncelikle başta Babağan Bektâşîleri ve Çelebi Bektâşîlerin pek çoğu olmak üzere şu anda Alevî olarak isimlendirilen ocak ve grupların hepsinde var olmayan bir kurumsal yap1 olmasına rağmen, müfredatta bütün Alevî nitelemeli ocak ve gruplarda varmış gibi bir algıya neden olacak tarzda işlendiği görülmektedir.

Musâhiblik bölgeden bölgeye ya da ocaktan ocağa farkl1 isimlendirilmesine rağmen, bu kurumsal yapının müfredatta tek isimle ve bütün gruplarda aynı keyfiyetle var olduğu şeklinde sunulduğu dikkat çekmektedir.

Alevî nitelemeli ocak ve gruplar arasında Musâhibliğin nasip alma, tarikata giriş (ikrâr) ya da ikrâr vermiş (tarikata girmiş) kişiler arasında ayrıca kardeşlik ahdi yapmaları şeklinde farklı şekillerde anlamlandırılıp uygulandığı bilinmektedir. Bu "yol bir sürek bin bir" anlayışının hakim olduğu gelenek açısından anlaşılır bir durumdur. Ancak bunun kamuoyunda yeterince kavrandığını söylemek zordur.

$\mathrm{Bu}$ zorluğun doğal olarak kaleme alınan kitaplara da yansıdığı göze çarpmaktadır. Musâhiblik özelinde görüldüğü üzere, özel uzmanlık alanı gerektiren ve hassasiyet içeren konuların, ders kitaplarında -usulüne uygun da olsa- alıntı yoluyla metne 
dönüşebildikleri bir vakıadır. Uzmanlık ve hassasiyet gerektiren konuların ders kitabında yazımı ve yazarların yetkinliğiyle alakalı bir durumun ayrı bir tartışma konusu olduğu görülmektedir. Bu noktada daha çok özel hassasiyet gerektiren konuların yazımında alan uzmanlığına yeterince yer verilip-veril(e)mediği ya da sistemin buna ne kadar uygun olduğu hususu ön plana çıkmaktadır. Ayrıca müfredatlarda yer alan ve birbirinden farkl disiplin alanlarına hitap edebilen ünitelerin, konulara göre özel alan uzmanlıkları bulunmayan yazarlar tarafindan yazılabilme ihtimali bahsi diğer bir konu olarak önümüzde durmaktadır. İşaret edilen bu hususlarla beraber neticede Alevî gelenekte farklı anlamlandırmalar, delillendirmeler ve uygulamaların olduğu bir konunun kitaplarda, bu farklılıkları görmezden gelircesine, bütün ocak ve gruplarda aynı şekliyle var olan bir olguymuş algısına neden olacak tarzda işlendiği oldukça dikkat çekmektedir.

Bahse konu olan ders kitaplarının, sınırları "Millî Eğitim Bakanlığ Ders Kitapları ve Eğitim Araçları Yönetmeliğı" ve "öğretim programlar/müfredatları" tarafından çizilen ve bu çerçevede kaleme alınan metinler oldukları açıktır. Musâhiblik konusunun müfredatın dayandığı mevzuat metinlerinde yer alış şekline bakıldığında, (galat-1 meşhur haliyle) Alevî-Bektâşî olarak nitelenen gelenek ya da ocak ve grupları homojen bir yap1 olarak görme ve yansıtma eğilimi gözlemlenmektedir. Alevî gelenek hakkında gerek mevzuat gerek müfredatta yer alan diğer konularda da bu eğilim ve yansıtma açıkça görülmektedir. Bunun ocak farklılıklarının yanı sira ocak ve gruplardaki tasavvufí ekol mensubiyeti ve silsile farklılıklarının pratiğe yansımasının bir ifadesi olarak dile getirilen "yol bir, sürek bin bir" esasına dayalı bir gelenek açısından doğru olmadığı açıktır.

Alevî gelenekte farklı uygulamaların olduğu bir konunun, mevzuat metinleri ve müfredatta geleneğe aykırı bir şekilde farklı tonlar1 ve tarzlar1 yok sayarak anlatılması hususunun, hem bilimsel hem pedagojik hem de sosyal yönü dikkate alınarak tekrar gözden geçirilmesinin yerinde olacağı değerlendirilmektedir. Bununla birlikte Musâhiblik konusu hakkında çalışmamızda çizilen çerçeve, müfredatta yer alan Alevî geleneğe ait kavram ve konulara, "Tasavvuf düşüncesi ve hayatı" konularının içinde yer verilmesinin isabetli olduğunu teyit etmektedir. 


\section{KAYNAKÇA}

Akın, Eren. "Kültürel Bellek Aktarımında Sosyal Örgütlenme ve Kontrol Mekanizması İlişkisi: Musahiplik Kurumu Örneği”. AlevilikBektaşilik Araştırmaları Dergisi 18 (2018): 295-318.

Aksüt, Hamza. Aleviler Türkiye-Iran-Irak-Suriye-Bulgaristan. Ankara: Yurt Kitap-Yayın, 2009.

Aktaş, Ali. "Kent Ortamında Alevîlerin Kendilerini Tanımlama Biçimleri ve İnanç Ritüellerini Uygulama Siklıklarının Sosyolojik Açıdan Değerlendirilmesi”. I. Türk Kültürü ve Hacı Bektaş Veli Sempozyumu Bildirileri. 449-484. Ankara: 1999.

Albayrak, Ali. "Alevi-Bektaşi Ritüelleri ve Temel Kurumlarından Hareketle Sosyal Bütünleşme”. Sûfî Araştırmaları 7/12 (2015): 21 36.

Alperen, Abdullah. “Alevî(lik) Modernleşmesine Dair Düşünceler”. Dem Dergi 2 / 6 (2009): 76-82.

Ayaz, Berna. "Balıkesir Çepni ve Tahtacılarında Musahiplik Geleneğinin Toplum Yaşamındaki İşlevi”. Alevilik Araştırmaları Dergisi 5 (2013): 103-114.

Bal, Hüseyin. Alevi-Bektaşi Köylerinde Toplumsal Kurumlar. İstanbul: Ant Yayınlar1, 1997.

Bal, Hüseyin. Sosyolojik Açıdan Alevi-Sünni Farklılaşması ve Bütünleşmesi. İstanbul: Ant Yayınları, 1997.

Başdemir, Hasan Yücel. "Din Dersleri ve Aleviliğin Aktarılması". Liberal Düşünce 16/63 (2011): 59-72.

Bayri, Hakan. Türkiye'de Kimlik Siyaseti Sorunu ve Ulusal Kimlik (1980 Sonrası Döneme Sosyo-Politik Bir Bakış). Doktora Tezi, Atatürk Üniversitesi, 2008.

Birdoğan, Nejat. Anadolu ve Balkanlar'da Alevi Yerleşmesi Ocaklar-Dedeler-Soyağaçları. İstanbul: Mozaik Yayınları, 1995.

Bozkurt, Nizam. Kur'an'da Alevî Erkânı Erkânname 100 Konu100 Deyiş- 100 Ayet. Ankara: 2008.

Bozkuş, Metin. “Alevî Yurttaşlara Yönelik Dinî Hizmetlerin İcrası Bağlamında Bir Teklif Denemesi”. Cumhuriyet Üniversitesi İahiyat Fakültesi Dergisi 10/1 (2006): 1-12.

Bulut, H. İbrahim - Çetin, Murat. "Gölyaka Alevîlerinin Dini İnanç Ve Yaşantıları". e-Makâlât Mezhep Araştırmaları. www.mezhep.org. 3/2 (2010): 165-206.

Bulut, H. İbrahim. “Türkmen Geleneğinde Sosyal Dayanışma Ve Kardeşlik Kurumu Olarak "Musahiplik". Kutlu Doğum Haftası "Hz. 
Peygamber Kardeşlik Ahlakı ve Kardeşlik Hukuku” Sempozyumu. 450-466. Ankara: 2013.

Buyruk. Haz. Sefer Aytekin. Ankara: Emek Basım-Yayımevi, 1958.

Buyruk. Haz. Fuat Bozkurt. İstanbul: 1982.

Cengiz, Recep. Çamiçi Beldesinde Dini Hayat; Alevilik Üzerine Sosyolojik Bir Araştırma. Yayımlanmamış Doktora Tezi, Fırat Üniversitesi, 2000.

Çağatay, Neşet. Bir Türk Kurumu Olarak Ahilik. Ankara: AÜIF Yayınları, 1974.

Dedekargınoğlu, Hüseyin. "Dede Garkın Ocağı'nda Musahiplik Uygulaması Örneği". Türk Kültürü ve Hacı Bektaş Veli Araştırma Dergisi 78 (2016): 91-112.

Dressler, Markus. Türk Aleviliğinin İnşası: Oryantalizm, Tarihçilik, Milliyetçilik ve Din Yazımı. İstanbul: İstanbul Bilgi Üniversitesi Yayınları, 2016.

Düzgün, Dilaver. "Divanü Lügati't-Türk'te Sosyal Normlar1 Karş1layan Kavramlar". Atatürk Üniversitesi Türkiyat Araştırmaları Enstitüsü Dergisi 35 (2007): 201-215.

Er, Pîri. Direnen Kültür Anadolu Aleviliği. İstanbul: Detay Yayınları, 2006.

Er, Tülay. Simav İçesi ve Çevresi Yaren Teşkilatı. Ankara: Kültür ve Turizm Bakanlığı Yayınları, 1988.

Ersal, Mehmet. "Alevi İnanç Sistemindeki Ritüelik Özel Terimler: Musahiplik", Turkish Studies 6/ 1 (2011): 1087-1110.

Ersal, Mehmet. Alevilik Kavramlar ve Ocak Sistemi -Cubuk Havzası Örneği-. Ankara: Türk Kültürü ve Hacı Bektaş Veli Araştırma Merkezi Yayınları, 2016.

Gökyay, Orhan Şaik. Dede Korkut Hikâyeleri. İstanbul: Kültür Bakanlığı Yayınları, 1976.

Gölpınarl1, Abdülbaki. Tasavvuf'tan Dilimize Geçen Deyimler ve Atasözleri. İstanbul: İnkilap ve Aka Kitabevleri, 1977.

Güngör, Özcan. Ârâf'taki Kimlik: Alevîlik/Bektâşilik. Ankara: Akasya Kitap, 2007.

http:// mufredat.meb.gov.tr/ProgramDetay.aspx?PID=319. Erişim: 02.06.2020.

http://mufredat.meb.gov.tr/Programlar.aspx. Erişim: 02.06.2020. 
Irmak, Y1lmaz - Hamarat, Handan. "Bingöl Aleviliğinde Dedelik Musahiplik Düsskünlük ve Cem”. Bingöl Üniversitesi Sosyal Bilimler Enstitüsü Dergisi 8/ 15 (2018): 211-232.

İmam Cafer-i Sadık Buyruğu. Haz. Adil Ali Atalay. İstanbul: Can Yayınları, 1998.

İnalcık, Halil. "Osmanlı Devletinin Kuruluş Problemi”. Doğu Batı 7 (1999): 9-22.

İnan, Abdülkadir. "Eski Türklerde ve Folklorda Ant”. Dil Tarih Coğrafya Fakültesi Dergisi 6/4 (1948): 279-290.

İpek, Yasin. "Tahtacilarda Alevi Terminolojisinden Kimi Örnekler", Alevilik. Haz. İsmail Engin, Havva Engin. 43-51. İstanbul: Kitap Yayınevi, 2004.

İpşirli, Mehmet. "Musâhib". Türkiye Diyanet Vakfı İslâm Ansiklopedisi. 31: 230. İstanbul: TDV Yayınları, 2006.

Kaşgarl1, Mahmud. Divanü Lûgati't-Türk. 4 cilt. Haz. Besim Atalay. Ankara: TDK Yayınları, 1986.

Kaya, Haydar. Musâhiblik. İstanbul: Engin Yayınc1lık, 1989.

Kaygusuz, İsmail. Aleviliğin Toplumsallaştırilmış Tapinç Kurumlarından Musahiblik. İstanbul: Alev Yayınları, 1991.

Keremî, Hasan Saîd. el-Hâdî ilâ Lügati'l-'Arab (I-IV). Beyrut: Dâru Lübnân, 1992.

Keskin, Yahya Mustafa. Değişim Sürecinde Kırsal Kesim Alevîliği Elazığ Sünköy Örneği. Ankara: İlâhiyât Yayınları, 2004.

Keskin, Yahya Mustafa. Kentleşme Sürecinde Alevîlik Gelenek ve Modernizm Arasında Gelgitler -Elazığ Örneği. İstanbul: Kıvılcım Ajans, 2009.

Korkmaz, Esat. Ansiklopedik Alevilik Bektaşilik Terimleri Sözlüğü. İstanbul: Ant Yayınları, 1994.

Kur'ân-ı Kerìm Meali. Çev. Halil Altuntaş - Muzaffer S,ahin (Ankara: Diyanet İşleri Başkanlığ Yayınları, 2009).

Kutlu, Sönmez. "Aleviliğin Dinî Statüsü: Din, Mezhep, Tarikat, Heterodoksi, Ortodoksi veya Metadoksi”. İslâmiyât 7/3 (2003): 3154.

Kutlu, Sönmez. Çağdaş İslamî Akımlar ve Sorunları. Ankara: Fecr Yayınları, 2008.

Kutlu, Sönmez. "Farklı İnanç Grupları ve Din Eğitimi". Kişisel Sönmez Kutlu. Erişim 01 Haziran 2020. http://www. sonmezkutlu.net/?Syf=26\&Syz=6026\&/Fark1\%C4\%B1\%C4\%BOnan\%C3\%A7-Gruplar\%C4\%B1-ve-Din-E\%C4\%9Fitimi. 
Macit, Sadullah. Ortaokul ve İmam Hatip Ortaokulu Din Kültürü ve Ahlak Bilgisi Ders Kitabı. İstanbul: FCM Yayınc1l1k, 2019.

Melikoff, İrene. Uyur İdik Uyardılar Alevîlik-Bektaşîlik Araştırmaları. Trc. Turan Alptekin. İstanbul: Cem Yayınları, 1994.

Okan, Murat. Türkiye'de Alevilik Antropolojik Bir Yaklaşım. Ankara: İmge Kitabevi, 2004.

Onat, Hasan. "Kızılbaşlık Farklılaşması Üzerine". İslâmiyât 7/3 (2003): 111-126.

Onat, Hasan. "Açılım Arayışları Gölgesinde Alevilik-Bektaşilik ve Kimlik Tartışmaları”, Dinî Araştırmalar 12/33 (2009): 37-46.

Onat, Hasan. "Kimlik Teoloji İlişkisi Bağlamında AlevîlikBektaşîlikle İlgili Kimlik Tartışmaları Üzerine”. Alevilik-Bektaşilik Araştırmalar Dergisi 1 (2009): 18-31.

Özdemir, Emrah. "Geleneksel Alevilikte Musahiplik ve Musahip Erkânı Samsun İli Havza ve Lâdik İlçeleri Örneği”. Hitit Üniversitesi Hacı Bektaş Veli Araştırma ve Uygulama Merkezi I. Uluslararası Hacı Bektaş Veli Sempozyumu. 2/ 731-751. Çorum: 2011.

Pakalın, Mehmet Zeki. Osmanlı Tarih Deyimleri ve Terimleri Sözlüğ̈̈. 3 cilt. İstanbul: MEB Yayınları, 1993.

Rençber, Fevzi. "Niyazi Arslan Dede ile Adiyaman'da Alevilik Üzerine". The Journal of Academic Social Science Studies 5/3 (2013): 547-569.

Rençber, Fevzi. "Adıyaman Yöresi Alevî Ocakları". OMÜ İlahiyat Fakültesi Dergisi 35 (2013): 159-170.

Rençber, Fevzi. Hakk Muhammed Ali Aşkı, Adıyaman Alevileri. Ankara: Gece Kitaplığı, 2016.

Sarıkaya, M. Saffet. Anadolu Alevîliğinin Tarihî Arka Planı (XI-XIII. Yüzyıl). İstanbul: Ötüken Yayınları, 2003.

Sarıkaya, M. Saffet. "Bektaşî ve Alevî Kültürünün Yazılı Kaynaklarından Fütüvvetnameler”. Anadolu'da Aleviliğinin Dünü ve Bugünü. Edit. Halil İbrahim Bulut. 367-377. Sakarya: Sakarya Üniversitesi Yayınları, 2010.

Sarıkaya, M. Saffet. "Bektaşî ve Alevî Kültürünün Yazılı Kaynağ1 Olarak Fütüvvetnameler”, Alevilik Araştırmaları Dergisi 4 (2012): 3566.

Sarıkaya, M. Saffet. "Alevilik-Bektaşiliğin Tasavvufi Boyutu Üzerine”. Türk Kültürü ve Hacı Bektaş Veli Araştırma Dergisi 82 (2017): 9-23.

Selçuk, Ali. Tahtacılar. İstanbul: Yeditepe Yayınları, 2004. 
Sinanoğlu, A. Faruk. Türk Kültüründe Alevi-Bektaşi Olgusu (Malatya Örneği). İstanbul: IQ Kültür Sanat Yayıncılık, 2008.

Soyyer, Yılmaz. Sosyolojik Açıdan Alevî Bektaşî Geleneği. İstanbul: Seyran, 1996.

Subaş1, Necdet. "Türk Modernleşmesi ve Alevîler". Geçmişten Günümüze Alevî-Bektaşî Kültürü. Edit. Ocak, Ahmet Yaşar. 110121. Ankara: Kültür ve Turizm Bakanlığı Yayınları, 2009.

Subaş1, Necdet. Alevilik Çalıştayları Nihai Raporu. Ankara: 2010.

Şahhüseyinoğlu, H. Nedim. Alevi Örgütlerinin Tarihsel Süreci. Ankara: İtalik Yayınları, 2001.

Şimşek, Eyup - Güngör, Özcan. "Alevi Yapısallaşmas1, Talepler ve Din Kültürü ve Ahlak Bilgisi Ders Kitaplarında AlevilikBektaşilik". Turkish Studies 8/3 (2013): 539-565.

Taşğın, Ahmet. Türkmen Aleviler -Diyarbakır Örneği-. İstanbul: Ataç Yayınları, 2006.

Taşkaya, Serderhan Musa. "Din Kültürü ve Ahlak Bilgisi Ders Kitaplarında Alevilik-Bektaşilik". 2. Uluslararası Türk Kültür Evreninde Alevilik ve Bektaşilik Bilgi Şöleni Bildiri Kitabı. Edit. Filiz Kılıç - Tuncay Bülbül. 2 cilt. 1/475-498. Ankara: Gazi Üniversitesi Türk Kültürü ve Hacı Bektaş Veli Araştırma Merkezi Yayınları, 2007.

Teber, Ömer Faruk. Bektâşî Erkânnâmelerinde Mezhebi Unsurlar. Ankara: Aktif Yayınları, 2008.

Teber, Ömer Faruk. "Osmanlı Belgelerinde Alevilik İçin Kullanılan Dini - Siyasi Tanımlamalar". Anadolu'da Aleviliğinin Dünü ve Bugünü. Edit. Halil İbrahim Bulut. 69-80. Sakarya: Sakarya Üniversitesi Yayınları, 2010.

Togan, A. Zeki Velidî. Oğuz Destanı Reşideddin Oğuznâmesi, Tercüme ve Tahlili. İstanbul: Ahmet Sait Matbaas1, 1972.

Tur, Seyit Derviş. Erkânname, Aleviliğin İslâm'da Yeri ve Alevi Erkânları. İstanbul: Can Yayınları, 2002.

Turan, İbrahim. "Din Kültürü ve Ahlak Bilgisi Öğretmenlerinin Aleviliğin Öğretimi ile İlgili Yeterlik Algıları", Hitit Üniversitesi Sosyal Bilimler Enstitüsü Dergisi 10/2 (2017): 879-902.

Türkel, Rifat. "Sofça Örnekleminde Kalburcu Şeyhi Pîr Ahmed Efendi ve Alevîlik Anlayışı". İnsan ve Toplum Dergisi 6/1 (2016): 4770.

Uğurlu, Ahmet. Alevilikde Cem ve Musâhiblik. İstanbul: Ufuk Matbaas1, 1991. 
Üçer, Cenksu. Alevîlikte Musâhiblik. 2. Baskı. Ankara: Araştırma Yayınları, 2015.

Üçer, Cenksu. "Alevî Nitelemeli Gelenek ya da Ocak ve Gruplar Hakkında Yapılacak Çalışmalarda Ocak Sisteminin Dikkate Alınmasının Önemi”. e-makâlât 12/2 (2019): 353-402.

Üçer, Cenksu. "Musâhiblik Kurumu Üzerinden Alevî Ocaklar ve Gruplar Hakkında Bazı Değerlendirmeler". Türk Kültürü ve Hacı Bektaş Veli Araştırma Dergisi 93 (2020): 11-35.

Üçer, Cenksu. Anadolu'da Alevî Ocakları ve Gruplan. Ankara: Ankara Okulu Yayınları, 2020.

Yalçınkaya, Ayhan. Alevilikte Toplumsal Kurumlar ve İktidar. Ankara: Mülkiyeliler Birliği Vakfı Yayınları, 1996.

Yaman, Ali. Alevilikte Dedeler Ocaklar. İstanbul: Ufuk Matbaacilik, 1998.

Yaman, Ali. "Alevîlerde Dedelik ve Dede Ocakları". Geçmişten Günümüze Alevî-Bektaşî Kültürü. Edit. Ahmet Yaşar Ocak. 178-202. Ankara: Kültür ve Turizm Bakanlığı Yayınları, 2009.

Yaman, Mehmet. Alevîlik İnanç-Edeb-Erkân. İstanbul: Ufuk Reklamcilık ve Matbaacilik, 2001.

Yıldırım, Rıza. Geleneksel Alevilik İnanç, İbadetler, Kurumlar, Toplumsal Yapr, Kolektif Bellek. İstanbul: İletişim, 2018.

Yıldız, Harun. "Alevî/Bektaşî Geleneğinde Musahiplik", Uluslarası Bektaşilik ve Alevilik Sempozyumu -I- BildirilerMüzakereler. 123-132. SDÜ Üniversitesi Yayınları: Isparta, 2005.

Yıldız, Harun. "Alevî-Bektaşî Geleneğinde Musahiplik". Geçmişten Günümüze Alevî-Bektaşî Kültürü. Edit. Ahmet Yaşar Ocak. 397-413. Ankara: Kültür ve Turizm Bakanlığı Yayınları, 2009.

Yıldız, Harun. "Amasya Yöresinde Alevîlik: Ocak ve Yapılar", Uluslararası Amasya Sempozyumu: Tarih-Dil-Kültür-Edebiyat 2 (2017), 1527-1555.

Y1lmaz, Feramuz - Doğan, H. İsmail - Özkan, Sümeyye - Öztürk, Yusuf. Ortaögretim Din Kültür ve Ahlak Bilgisi. Ankara: Devlet Kitaplar1, 2018.

Yılmaz, Hüseyin. "Alevîlik-Sünnîlik Açısından Din Kültürü ve Ahlak Bilgisi Dersleri". Cumhuriyet Üniversitesi Ilahiyat Fakültesi Dergisi 13/2 (2009): 189-209.

Zengin, Halise Kader. "Din Kültürü Ve Ahlak Bilgisi Dersi Öğretim Programlarında Devletin Alevilik Algısı (Karşılaştırmalı Bir Analiz)". Elektronik Sosyal Bilimler Dergisi 12/47 (2013): 63-87. 


\section{Summary}

This article deals with the subject of Musahiblik how it is handled in the curriculum of Religious Culture and Ethics Course. The institution of Musahiblik mentioned here is found in some "ocak"s (lodge) and groups named Alevi. However, it continues to exist with different interpretations and practices among these "ocak"s and groups. The Musahiblik that commonly indicates the brotherhood of the two married families in the worldly life and the Hereafter, expresses a traditional institutional structure involving social solidarity.

The Musahiblik institution that maintains influence in some "ocak"s and groups member of Alevi tradiation has fed from the same sources with many formations that in different regions of Anatolia; for example, Yaren, Barana, Delikanlı Teşkilat1, Gezek, Muhabbet, Oda Tesskilatı, Sohbet, Sira, Perde, Arfana etc. It is understood that the Musahiblik is a form according to their social and religios lives of the Alevi ocaks and groups that shaped according to system of tribe, lineage, clan and sufi order life.

The expression of "Alevî Tradition" in the article has expressed the conception shaped in the context of sufi life that the 'ocak's and groups that are called as Alevi have itself. The "ocak"s have mean the traditional structure which constitutes an 'Ocak' system that is the subject of the article and the "groups" have expressed the affiliation in the context of organization within the framework of different understandings arising from urbanization.

Today the tradition that is called as Alevi have a traditional structure which constitutes an 'Ocak' system. As known, among the members of the Alevi tradition, every Dede and Talib depend on the 'ocak'.

All Alevi groups still have a formation constituted from metbu/main ocak and sub-ocaks connected to the main ocak in accordance with the system of main elite group and sub-groups affiliated with it. The ocak system has carried up to now. In this context, the word "Alevi" has been used in naming a higher body above several groups like Bektashis, Erdebil Sufiyan Süreği Talibleri (Kızılbash), Tahtacıs, Hubyars, Dede Garkınlıs, Ağu İçens, Baba Mansurlus, Keçeci Babalıs, Kureyşanlıs, Sinemillis etc. As a matter of fact, the examples that are widespread in Anatolia such as; Ağuçan, Baba Mansur, Hacı Bektaş, Dede Garkın, Hasan Dede, Keçeci Baba, Hubyar, Şücaaddin Veli etc.make the matter clear.

According to data presented by the studies on this subject there are five main elite groups (ana ocaks) among Alevis namely Hacı Bektâş Ocağı, Dede Garkın Ocağı, Baba Mansur Ocağı, 
Avuçan/Ağuçan Ocağı ve Hasan Dede Ocağı and several sub-groups affiliated with them. It is suitable to give the main elite group of Hac1 Bektas and sub-groups connected to it as an example to better understand the structure of main body and affiliated sub-groups. Sultan Samıt, Güvenç Abdal, Koçu Baba, Hüseyin Gazi, Seyit Cemal Sultan, Şeyh/Işık Çakır, Sarı İsmail and Kızıldeli (Seyit Ali Sultan) are the sub-groups that are affiliated with Hac1 Bektass.

All the Ocaks named Alevi have different chains of authorities (silsilahs or shajaras) and they were also affiliated with various Sufi orders. These differences are the main reason for the emergence of some differences about main elements among the members of the Alevi tradition. Depending on these differences, different understandings and practices have emerged in the acceptance of "Haq, Muhammad, Ali", four doors and forty levels, manners and ceremonies/etiquettes, books about Alevi manners and ceremonies/etiquettes, 'Cem's, 'semah's, mystical poems (deyişs) and musical ballads (nefes) recited during cems, social institutions such as 'musahiblik'.

There are three different approaches in Alevi tradiotion about Musahiblik, for example, it is regarded as a "nasip alma" in Bektaşi groups; an entrance to the "tarikat" in some "Ocak"s; the brotherhood of the two married families that entered the "Tarikat" before in the other "ocak"s. This is due to the phenomenon of different understandings. Because all the Ocaks named Alevi have different chains of authorities (silsilahs or shajaras) and they were also affiliated with various Sufi orders.

However, the radical changes experienced due to modernity, secularization, industrialization, urbanization, specialization, migration etc. have radically shaken the social corporate structures like Dedelik, Düşkünlük and Musahiblik etc. The transition period experienced in Turkey and the institutionalization efforts of Alevi groups in the cities will determine and clarify how to continue the traditional institutions or whether it will continue or not. Today, as a result of modernization and urbanization etc. seen in the world and our country, the institutions like the Musahiblik started to lose its function and to be forgetten.

Depending on developments in the world and our country, some issues deemed important for he Alevi tradition started to take place in the curriculum of Religious Culture and Ethics Course since 2005. One of these issues is the Musahiblik. It is observed that the subject of Musahiblik is processed in 7th grades in the primary education and 12 th grades in the secondery education today. 
It stands out in the curriculum that the musahiblik is processed in a manner that causes a perception as if it existed in all the Alevi "ocak"s and groups. It is also seen that the Musahiblik is presented as a single name and as if it existed with the same interpretations and practices among all these "ocak"s and groups. 